\author{
L.M. Soltys, I.F. Mironyuk, T.R. Tatarchuk, V.I. Tsinurchyn
}

\title{
Zeolite-based Composites as Slow Release Fertilizers (Review)
}

\author{
Vasyl Stefanyk Precarpathian National University, Ivano-Frankivsk, Ukraine,e-mail: soltys86@gmail.com
}

\begin{abstract}
One of the most important problems of agriculture is finding new methods to increase soil fertility and productivity. The use of fertilizers increases the efficiency of nutrients, however, their uncontrolled use leads to leaching and contamination of the environment. Zeolite is considered a natural element that has no negative environmental effects. Its ion exchange properties are important for plant nutrition due to its cation exchange ability and porosity. Zeolites added to fertilizers give a double result when applied to soil: provide long lasting action of fertilizer (prolongation effect) and prevent nutrient leaching. This article analyzes current literary sources of information on the use of zeolite-based composites as a prolonged action fertilizer in agriculture, as well as their impact on nutrient retention and release into the soil.

Keywords: zeolite, slow release fertilizers, surfactant-modified zeolite, leaching, nutrients uptake, retention, cation exchange capacity, soil amendments.
\end{abstract}

Received 02.02.2020; accepted for publication 15.03.2020.

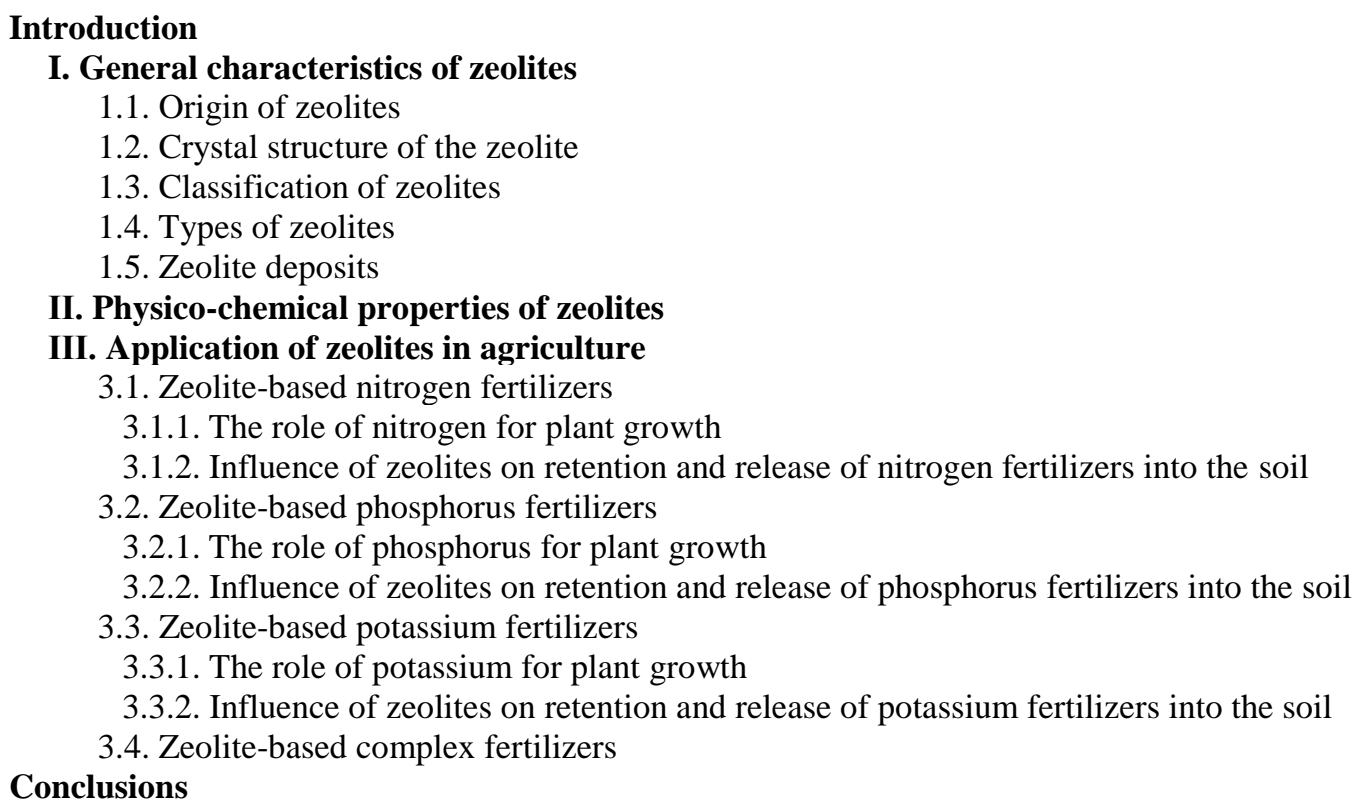

\section{Introduction}

Agriculture is very important for people all over the world due to the massive increase in population and the growing requirements for food. This, in turn, leads to significant use of fertilizers to improve soil condition and increase yields quickly. However, the uncontrolled use of fertilizers contributes not only to the degradation of soil quality but also to the leaching of soils due to the high solubility of fertilizers. Therefore, they are less conducive to plant growth and more conducive to environmental and human health problems [1-3].

Improving fertilizer efficiency is a very important task that seeks to find ways to increase nutrient efficiency, minimize fertilizer losses from physical, 
chemical and biological processes, and reduce environmental impact. An example of this method is the introduction of slow release fertilizer into the soil, which releases nutrients more slowly than conventional fertilizer, or controlled release, in which the rate, structure and release period are controlled during its use. Ideally, fertilizer release should be faster in the beginning and slower during plants growing in order to meet any nutritional needs that change over the growing period. Particular emphasis is placed on the newest coating methods and release experiments [4-10].

The retention of nutrients and water in agricultural soils results in greater yields and prevents the flow of water. The unique physical and chemical properties of zeolites, combined with their high prevalence in sedimentary rocks, have made them useful in many agricultural applications. These minerals are regarded as soil conditioners to improve their physical and chemical properties. Ion exchange properties of zeolite can be used in agriculture due to its large porosity and high ability to exchange cations. They can be used as nutrient carriers. Natural and surface-modified zeolites can effectively retain water and nutrients, including $\mathrm{NH}_{4}^{+}, \mathrm{NO}_{3}^{-}, \mathrm{PO}_{4}^{3-}$, $\mathrm{K}^{+}$and $\mathrm{SO}_{4}^{2-}$, in their unique porous structure. The introduction of zeolite into the soil has increased yields and promoted the efficient use of nutrients. Zeolites are also used as a sustained-release fertilizer carrier [1,2,11$15]$.

The aim of this study was to summarize literature data on the effects of zeolite applications as a slow release fertilizer on crops and also its ability to retain water and nutrients.

\section{General characteristics of zeolites}

\subsection{Origin of zeolites}

Axel Fredrik Cronstedt (1756) is swedish mineralogist, who first discovered zeolites at a copper mine in Sweden. From the Greek "zeolite" is translated as "boiling stones" as it is able to foam when heated to $200^{\circ} \mathrm{C}$. Zeolites are natural crystalline aluminosilicates. They are one of the most common minerals, which are presented in sedimentary rocks. Despite their long history, their commercial production and use for agriculture began only in the 1960s in Japan. A brief review of the literature indicated that Japanese farmers used zeolite rock for many years to control the moisture content and increase the $\mathrm{pH}$ of acidic volcanic soils $[11,12,16]$.

\subsection{Crystal structure of the zeolite}

Zeolite is a crystalline substance with a structure characterized by tetrahedral $\mathrm{SiO}_{4}^{4-}$ rings, each of which consists of four oxygen atoms surrounding the cation, with some of the silicon atoms being replaced by aluminum atoms $\left(\mathrm{AlO}_{4}^{5-}\right)$ (Fig. 1.) [17]. These rings contain open cavities in the form of channels, which have certain sizes, through which the adsorption of the substance by zeolites occurs. Only molecules smaller than the diameter of the channel can penetrate the zeolite through these channels. It is known that the inner surface area of these channels reaches several hundred square meters per gram of zeolite, making zeolites extremely effective ion exchangers [11, 12, 16, 18].

Pores and cavities are key characteristics of zeolite materials. Pores and interconnected cavities are occupied by cations and water molecules. Cation exchange of zeolites proceeds by diffusion of cations, for example, $\mathrm{Ca}^{2+}, \mathrm{Na}^{+}$cations, which are in the cavities and channels of zeolites, can be replaced by $\mathrm{K}^{+}, \mathrm{Mg}^{2+}$, $\mathrm{Fe}^{2+}$. Zeolite water contained in the cavities can be lost through these channels when heated without changing the volume of the mineral. Dehydrated zeolite can again absorb water.

General empirical formula of zeolite is $M_{2 / n} O$. $\mathrm{Al}_{2} \mathrm{O}_{3} \cdot x \mathrm{SiO}_{2} \cdot y \mathrm{H}_{2} \mathrm{O}$, where $\mathrm{M}$ is alkaline or alkaline earth metal; $n$ is the degree of its oxidation; $x$ is the number of $\mathrm{SiO}_{2}$ molecules (from 2 to 10); $y$ is the number of $\mathrm{H}_{2} \mathrm{O}$ molecules (from 2 to 7) [11, $\left.12,16,18\right]$.

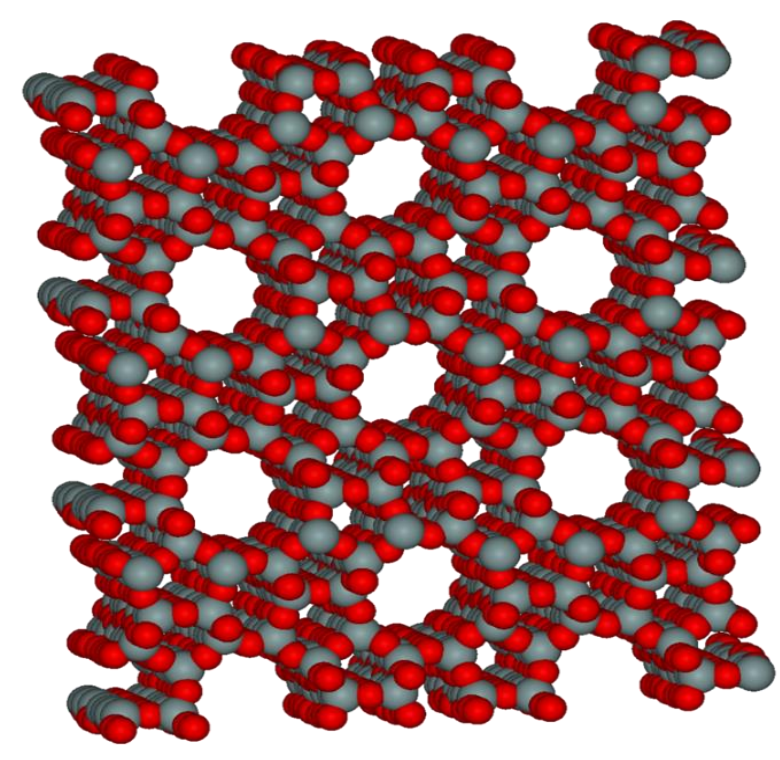

Fig. 1. Microporous molecular structure of zeolite [17]. 


\subsection{Classification of zeolites}

The $\mathrm{Si} / \mathrm{Al}$ ratio is an important characteristic of zeolites. The charge imbalance due to the presence of aluminum in the zeolite rings determines the ion exchange property of the zeolites and induces potential acidic positions. The $S i / A l$ ratio is inversely proportional to the cation content but directly proportional to the heat resistance. Molecular sieves of Si have a neutral base, hydrophobic character and have no ion exchange or catalytic properties. Zeolites are classified based on the ratio of $S i$ and $A l$ as follows: a) zeolites with low $S i / A l$ ratio (from 1.0 to 1.5 ); b) zeolites with an average $S i / A l$ ratio (from 2 to 5); c) zeolites with high $S i / A l$ ratio (from 10 to several thousand) $[11,12,16]$.

Flanigen [11] classified zeolites based on pore diameter, namely:

a) finely porous zeolites ( 8 rings) with a diameter of free pores of $0.3-0.45 \mathrm{~nm}$;

b) medium-porous zeolites (10 rings) with a diameter of free pores of $0.45-0.6 \mathrm{~nm}$;

c) large porous zeolites (12 rings) with a diameter of free pores of $0.6-0.8 \mathrm{~nm}$;

d) extra-large porous zeolites (14 rings) with a diameter of free pores of $0.8-1.0 \mathrm{~nm}$.

\subsection{Types of zeolites}

About 50 mineral species of natural zeolites are known and more than 150 species have been synthesized. The most common: clinoptilolite, heulandite, natrolite, phillipsite, laumontite, mordenite, chabazite, stilbite, harmotome, ferrierite, analcime, erionite. They are formed at a temperature of $250^{\circ} \mathrm{C}$ and a pressure of 200 $300 \mathrm{MPa}$ as a result of hydrothermal, hydrothermalmetasomatic, diagenetic and metamorphic processes in volcanic (basalt-andesite-rhyolite) and volcanicsedimentary rocks. Often zeolites are also formed in autometasomatosis of rocks with nepheline, leucite, volcanic glass, feldspars [19].

\subsection{Zeolite deposits}

There are about 1000 major zeolite deposits (with stocks over 105 tons) in more than 40 countries worldwide. Clinoptilolite, mordenite, chabazite have industrial value; analcime, phillipsite, and others are also promising. Zeolite deposits are known in Iceland, New Zealand, USA, Japan, Russia (Kamchatka), the Caucasus. Recently, new types of zeolite rocks have been discovered. They were formed under exogenous conditions as a result of the conversion of volcanic tuffs and ash of ancient volcanoes in marine conditions. Examples are deposits in the USA, East Africa, Japan, Ukraine (Transcarpathian region), Turkmenistan, and more. World reserves of zeolite raw materials amount to several tens of billions of tons. The main reserves (10-20 billion tons) - in the USA, Japan, CIS countries. In Italy and the Balkans there are from 1 to 10 billion tons of zeolites in each country [19].

The Sokyrnytske (Khust district of Transcarpathian region) zeolite deposit (clinoptilolite) has been thoroughly explored in Ukraine and the search evaluation of Voditsky (Rakhiv district of Transcarpathian region) of zeolite (mordenite) deposit was performed. Separate deposits are found in the Crimean folded region and also in the Azov region.

"Galosh" site on the outskirts of Sokyrnytsi village with reserves of 44.9 million tonnes is being developed by "Zeolit" company. A similar zeolite ore was found in the outskirts of the villages of Kraynikovo, Danilovo and Lipcha (Ukraine). The reserves and estimated resources of the field and adjacent areas are estimated at 463 million tons. In recent years, the market for the sale of zeolites has been lost due to the complete lack of control over the quality of raw materials on the content of zeolites and shifting into fractions. In just 25 years, only 250,000 tonnes of the 126.1 million tonnes was mined. Transcarpathian zeolites have the highest quality in Europe [19].

\section{Physico-chemical properties of zeolites}

Zeolites - minerals with pores of molecular size ( $4 \AA$ ) that are able to absorb and reliably contain a variety of impurities. Among them: heavy metals (lead, cadmium, zinc, strontium, chromium), radionuclides, nitrates and nitrites, ammonium salts, petroleum products and many other chemical and biological contaminants. They are characterized by resistance to significant temperature fluctuations, to ionizing radiation and to aggressive environment, sufficient mechanical strength, absence of toxic compounds, contamination of the mineral by microorganisms is excluded [20].

Zeolites vary widely in their chemical composition, especially in terms of $\mathrm{SiO}_{2}, \mathrm{CaO}, \mathrm{K}_{2} \mathrm{O}, \mathrm{Al}_{2} \mathrm{O}_{3}, \mathrm{Na}_{2} \mathrm{O}$ and $\mathrm{Fe}_{2} \mathrm{O}_{3}$ content $[11,12]$. The chemical composition of zeolites (on the example of clinoptilolite Sokyrnytske deposit of minerals [21]) is shown in Table 1.

Zeolites, due to the features of the crystal structure, have adsorption, ion exchange and catalytic properties. They are potential adsorbents due to their microporous structure's ability to adsorb molecules at relatively low pressure. Zeolites are involved in catalytic reactions due to fixed pore sizes and active sites in the crystalline lattice $[11,12]$.

Table 1

The chemical composition of zeolites

\begin{tabular}{|c|c|}
\hline Oxide & \% (wt.) \\
\hline $\mathrm{SiO}_{2}$ & 70.21 \\
\hline $\mathrm{Al}_{2} \mathrm{O}_{3}$ & 12.27 \\
\hline $\mathrm{Fe}_{2} \mathrm{O}_{3}$ & 1.2 \\
\hline $\mathrm{FeO}$ & 0.55 \\
\hline $\mathrm{TiO}_{2}$ & 0.14 \\
\hline $\mathrm{MnO}$ & 0.073 \\
\hline $\mathrm{P}_{2} \mathrm{O}_{5}$ & 0.033 \\
\hline $\mathrm{K}_{2} \mathrm{O}$ & 3.05 \\
\hline $\mathrm{Na}_{2} \mathrm{O}$ & 1.77 \\
\hline $\mathrm{SO}_{3}$ & 0.10 \\
\hline $\mathrm{CaO}+\mathrm{MgO}$ & 10.604 \\
\hline
\end{tabular}


Anhydrous zeolite is a microporous crystalline «sponge» with a pore volume of up to $50 \%$ of the volume of the zeolite frame. Such a «sponge» having an inlet diameter of 0.3 to $1 \mathrm{~nm}$ (depending on the zeolite type) is a highly active adsorbent. The diameters of the inlets of the sponge are strictly defined in size. In this connection, there is a molecular sieve selection in the sorption of molecules from gases and liquids. Properties of zeolites allow to separate molecular mixtures even in cases where the difference in the size of the molecules is from 10 to $20 \mathrm{~nm}[11,12]$.

The ion-exchange properties of zeolites are determined by the chemical affinity of ions with the zeolite crystalline structure. In this case, as with the adsorption of molecules, it is necessary to match the size of the inlets into the zeolite frame and the replacement ions. Ion exchange on zeolites manages to separate ions, the extraction of which by other methods is often of great complexity. They are one of the largest cation exchangers, and their cation exchange capacity is two to three times greater than that of other types of minerals found in soils $[11,12]$. Clinoptilolite has a value of cation exchange capacity relatively small $(2.25 \mathrm{mEq} / \mathrm{g})$, with high selectivity of cations:

$$
\mathrm{Cs}>\mathrm{Rb}>\mathrm{K}>\mathrm{NH}_{4}>\mathrm{Ba}>\mathrm{Sr}>\mathrm{Na}>\mathrm{Ca}>\mathrm{Fe}>\mathrm{Al}>\mathrm{Mg}>\mathrm{Li}
$$

Chemical land reclamation, which improves soil properties, plays a special role in the agriculture. The use of natural zeolites as ameliorants is a new area of research. The mechanism of action of natural zeolites as ameliorants is quite diverse and has not yet been fully understood. Zeolites enhance the soil structure, increase its permeability, accumulate important nutrients for plants, such as $N$ and $K$ in the form of exchangeable cations and adsorb $\mathrm{NH}_{3}$, and then slowly give away during plant growth, acting as a prolonger. The mobile forms of fertilizers adsorbed by zeolite are retained from leaching, reducing the loss of ammonium nitrogen by nitrification and evaporation, resulting in improved plant nutrition with nitrogen and potassium. Due to ion exchange zeolites reduce the acidity of soils, increase their ability to retain water. Zeolites in soil bind heavy metals, preventing their entry into plants. In addition, the zeolite is resistant to erosion and stored in the soil without further transformation. Zeolites contributes to physical and chemical properties of the soils, enhance their biological activity and increase in the number of useful soil microorganisms [20].

\section{Application of zeolites in agriculture}

Effective farming requires a high rate of nutrient input and effective irrigation systems to increase yields. However, if the nutrients are brought into the soil quickly enough, a significant part of them can be washed away, which contaminates the water resources and also reduces the yield of the products. Zeolites are widely used in various studies to improve the agriculture efficiency. They have some influence on the physical behavior of the soil, in particular, reducing the soil bulk density and increasing the soil porosity. These impacts, along with the large internal pore volume in the zeolite structure, can effectively increase the soil's water permeability. The exceptional chemical and physical properties of natural zeolites, especially the high cationic ability and strong affinity for $\mathrm{NH}_{4}^{+}$and $\mathrm{K}^{+}$, allow them to be used to maximize the efficiency of nitrogen use in agriculture. However almost all natural zeolites and most artificial zeolites do not have a high affinity for anionic fertilizers,
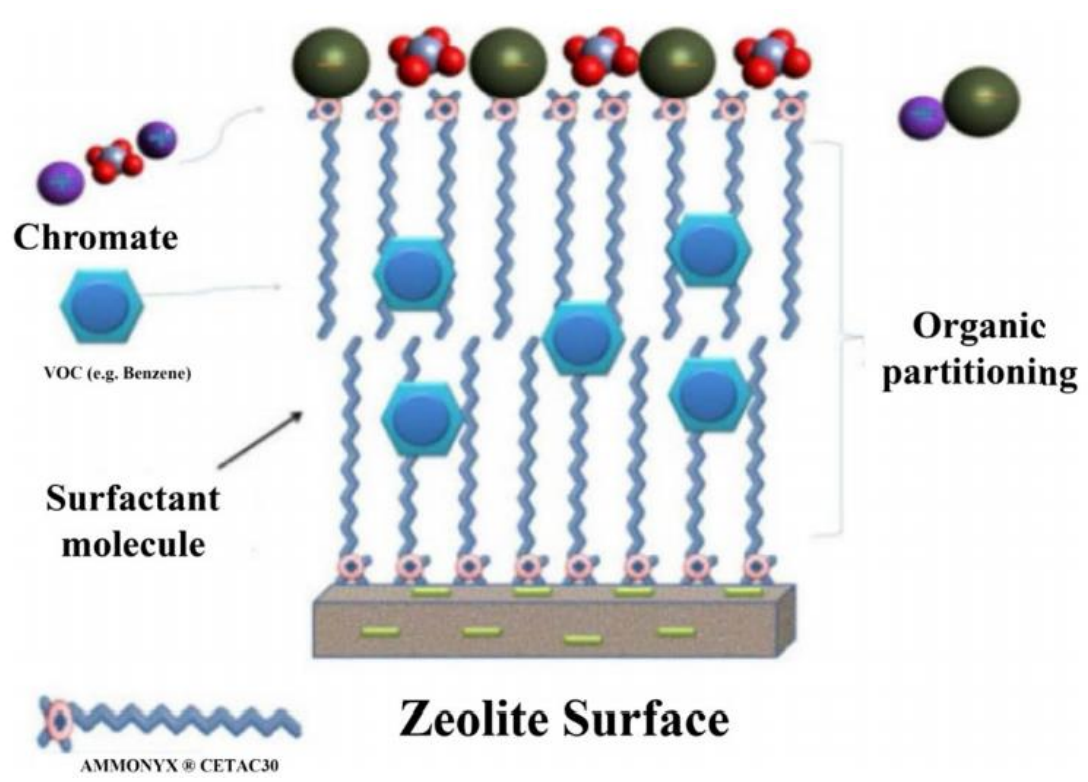

Fig. 2. Scheme diagram of surfactant-modified zeolite (SMZ), a multifunctional adsorbent for trapping organic molecules, anionic species, and cations [25]. 
such as $\mathrm{NO}_{3}^{-}, \mathrm{PO}_{4}^{3-}$, and $\mathrm{SO}_{4}^{2-}$. The chemical modification of zeolite surface by cationic surfactants lets to obtain multifunctional adsorbents [2, 13, 18, 2224].

Bowman et al. [24] proposed the concept of zeolite surface modification using surfactants. Surfactant molecules form two layers on the zeolite outer surfaces. The lower layer is formed by electrostatic interaction between the negatively charged zeolite surface and the positively charged surfactant groups, with the upper layer connected to the lower hydrophobic forces between the groups of the surfactant tails in both layers. According to the configuration of the two-layer surfactant, the zeolite changes the surface charge to the opposite, which leads to a higher affinity for negatively charged anions, and the sorption and retention of anions refers to the surface anion exchange. Due to the fact that the surfactant attaches only to the outer surface of the zeolite, the cation-exchange positions located inside the pores are still available for cation exchange. Therefore, the loading of cationic nutrients (such as $K$ ) into the pores can be achieved simultaneously with the loading of anionic nutrients (such as $\mathrm{NO}_{3}^{-}$and $\mathrm{PO}_{4}^{3-}$ ) on their surface [24]. The scheme of a typical surfactant-modified zeolite (SMZ) is shown in Fig. 2 [25].

Prior to any commercial introduction of soil improvers, studies should be conducted to assess the risk of leaching of toxic surfactants to which the zeolite surface is weakly attached. As a rule, the effect of zeolite application on the physical and chemical properties of the soil depends on various experimental conditions, type of zeolite and application standards, method of application, texture and structure of the soil, size and density of zeolite particles and also the salinity of the water $[2,13,18,22,26]$.

\subsection{Zeolite-based nitrogen fertilizers}

\subsubsection{The role of nitrogen for plant growth}

Nitrogen is one of the main biogenic elements. It is a part of protein substances and many other naturally vital organic compounds for plants: lipids, chlorophyll, alkaloids, phospholipids, proteins, many enzymes. However only the reduced form of nitrogen can participate in the synthesis of amino acids and proteins in plants. All its forms are restored to ammonia due to chemical and biological changes in soil or transformations directly in plants. Nitrogen content in some plant proteins is $14.7-19.5 \%$. In the dry matter of plants its content ranges from 0.4 to $5 \%$. The crops need the nitrogen more compared to other elements [27, 28].

Insufficient nitrogen supply inhibits plant growth and development, resulting in reduced productivity. The lack of nitrogen primarily affects the change in leaf color. Stems become thin, elongated, slightly branched, leaf size decreases, reproductive organ formation deteriorates. Excessive nitrogen nutrition disrupts the normal life of the plant organism, which, in turn, leads to undesirable effects: decreases the content of solids in grains and root crops, decreases the minerals content, decreases the resistance of fruits and vegetables to mechanical damage during transportation and processing in the post-harvest period, deteriorates their taste qualities, increases the accumulation of a significant amount of intermediates (free amino acids, nitrates, nitrites, etc.), sensitivity of plants to diseases and pests increases [27, 28].

Nitrates $\left(\mathrm{NO}_{3}^{-}\right)$, ammonium compounds $\left(\mathrm{NH}_{4}^{+}\right)$, in limited quantities - organic anions $\left(\mathrm{NO}_{2}^{-}\right)$, soluble amides and amino acids - are the main nitrogen sources for plant nutrition in natural conditions. Plants equally use ammoniacal and nitrate forms of nitrogen, but under certain conditions the best source of nitrogen for plants is $\mathrm{NH}_{4}^{+}$cations, in others $-\mathrm{NO}_{3}^{-}$anions. Thus, in the acidic environment plants absorb nitrate better, in the neutral environment plants absorb ammonium form of nitrogen $[27,28]$.

The modern assortment of nitrogen fertilizers produced by industry is divided into follow groups: ammonia, nitrate, amide, etc. A separate group consists of slow release nitrogen fertilizers.

\subsubsection{Influence of zeolites on retention and} release of nitrogen fertilizers into the soil

The strong affinity of zeolites to $\mathrm{NH}_{4}^{+}$cations can be widely used to improve its retention and release into the soil. The degree of $\mathrm{NH}_{4}^{+}$retention by zeolite minerals may vary depending on the $S i$ / $A l$ ratio, the mobile and exchangeable zeolite cations, the pore size and structure of these materials, $\mathrm{pH}$, contact time, temperature and concentration of other ions in the soil [16, 29-33].

In [31], the authors investigated the effect of natural zeolite on soil nitrogen dynamics by controlling the absorption of $\mathrm{NH}_{4}^{+}, \mathrm{Al}^{3+}, \mathrm{Fe}^{2+}, \mathrm{Mn}^{2+}$ and $\mathrm{Mg}^{2+}$ cations in powdered zeolite and its mixture with soil. The procedure is as follows: $100 \mathrm{~g}$ of powdered zeolite was added to $1 \mathrm{~L}$ of solution (prepared from $\mathrm{NH}_{4} \mathrm{Cl}, \mathrm{FeSO}_{4}$, $\mathrm{MnSO}_{4}, \mathrm{CaCl}_{2}$ and $\mathrm{MgCl}_{2}$ salts) containing $50 \mathrm{mg} \mathrm{NH}_{4}^{+}$, $30 \mathrm{mg} \mathrm{Fe} e^{2+}, 10 \mathrm{mg} \mathrm{Mn}{ }^{2+}, 200 \mathrm{mg} \mathrm{Ca}^{2+}$ and $100 \mathrm{mg}$ $\mathrm{Mg}^{2+}$, and obtained solution stirred for 1, 2, 4, 10, 20, 40, 80, 160, 320, 540 and 960 minutes. Powdered zeolite, with particles less than $45 \mu \mathrm{m}$, contained $57.2 \%$ clinoptilolite. Its chemical composition was as follows: $70.9 \% \mathrm{SiO}_{2} ; 1.1 \% \mathrm{Al}_{2} \mathrm{O}_{3} ; 1.4 \% \mathrm{Fe}_{2} \mathrm{O}_{3} ; 2.9 \% \mathrm{CaO}$; $3.3 \% \mathrm{~K}_{2} \mathrm{O} ; 0.80 \% \mathrm{MgO} ; 0.54 \% \mathrm{Na}_{2} \mathrm{O} ; 4.6 \% \mathrm{H}_{2} \mathrm{O}^{+}$; $4.3 \% \quad \mathrm{H}_{2} \mathrm{O}^{-}$; self-ignition loss $2.78 \%$. The concentrations of $\mathrm{Ca}, \mathrm{Mg}, \mathrm{Mn}$ and $\mathrm{Fe}$ were determined by atomic absorption spectrophotometry, and $\mathrm{NH}_{4}^{+}$ cations were determined photometrically by the Nessler and Jendrasik method. A methodology based on the direct displacement of saturated $\mathrm{NH}_{4} \mathrm{Cl}$ salt was used to determine the cationic sorption capacity. According to it the adsorbed $\mathrm{NH}_{4}^{+}$cation was directly replaced by a $\mathrm{KNO}_{3}$ solution. $\mathrm{NH}_{4}^{+}$cation was determined in $\mathrm{KNO}_{3}$ extract after washing with acidified $\mathrm{NaCl}$ solution by distillation and titration or photometry. There were four variants of the experiment: control variant without any fertilizer (K); $600 \mathrm{~kg}$ of zeolite per hectare (Z1); $900 \mathrm{~kg}$ of zeolite per hectare (Z2); $1200 \mathrm{~kg}$ of zeolite per hectare (Z3). All variants were performed four times. The experiments were carried out on white cabbage at the field with area about $50 \mathrm{~m}^{2}(10 \times 5 \mathrm{~m})$.

More than $90 \%$ of the observed cations were detected in the zeolite in the first few minutes of the laboratory experiment, which is a very rapid absorption, 
and the ammonia cations reacted the fastest. Reduced ammonium content was found in variants with zeolite 1 month after zeolite application compared to non-zeolite variants due to specific fixation of $\mathrm{NH}_{4}^{+}$cations in the zeolite lattice $(92.5 \mathrm{mg}$ in the control variant and 77.2 $81.0 \mathrm{mg}$ per $\mathrm{kg}$ of soil in the tested variants). Three months later, the ammonium content in variants with zeolite increased from $24 \%$ to $59 \%$ compared to the control variant due to the gradual release of ammonium from the zeolite lattice. Six months after the application of the zeolite, statistically significant differences were found not only between the control variant and the zeolite variants, but also between individual variants with different doses of zeolite $(\mathrm{H}=14.201 ; \mathrm{P}=0.003$ according to the Kruskal-Wallis test) [31,33]. Dynamics of ammonium nitrogen in soil over 5 months of observations confirmed that zeolite could be considered as a slow-release nitrogen fertilizer. The presence of zeolite in the soil slows down the nitrification process to some extent, so the process of leaching of nitrate into the deeper layers of the soil is not as intense. Therefore, the use of zeolite in soil has a beneficial effect on the environment, preventing the leakage of nutrients (especially nitrogen) into the soil water and increasing the efficiency of those nutrients entering the soil. However, this does not adversely affect the quality of the products grown $[31,33]$.

The work [32] shows the use of zeolite together with cattle manure to improve the efficiency of nitrogen use directly in sunflower grown on sandy soils. The experiment was conducted using two irrigation regimes (full irrigation and limited irrigation) and holistic processing with five fertilizer strategies (F1: urea; F2: urea + compost pus with $0 \%(\mathrm{w} / \mathrm{w})$ zeolite; F3: urea + compost pus with $7 \%(\mathrm{w} / \mathrm{w})$ zeolite; F4: urea + compost pus with $14 \%$ (w/w) zeolite; F5: urea + compost pus with $21 \%(\mathrm{w} / \mathrm{w})$ zeolite). It was shown that combined cattle pus, urea and clinoptilolite $(14-21 \%)$ was significantly more effective in improving the most quantitative and qualitative characteristics of sunflower than the urea itself or urea with cattle manure. It is known that zeolites adsorb $\mathrm{NH}_{4}^{+}-\mathrm{N}$ contained in compost in their pores. Nitrifying bacteria using $\mathrm{NH}_{4}^{+}-\mathrm{N}$ as a precursor for $\mathrm{NO}_{3}^{-}$production cannot access zeolite pores. Thus, zeolites make $\mathrm{NH}_{4}^{+}-\mathrm{N}$ inaccessible to nitrifying bacteria and reduce the transformation of $\mathrm{NH}_{4}^{+}$to $\mathrm{NO}_{3}^{-}$, thereby preventing the leaching of $\mathrm{NO}_{3}^{-}$. Because zeolite reduces the leaching of $N$ under these conditions, it increases the $N$ available to the plant and, therefore, the efficiency of $N$ using. Studies have shown that adjusting soil with manure and zeolite is a beneficial approach to reducing fertilizer application rates and improving the sustainability of agricultural systems.

In [34] adsorption and leaching experiments were conducted to investigate the use of clinoptilolite as a soil improver to increase $\mathrm{N}$ retention and reduce nitrate $\left(\mathrm{NO}_{3}^{-}\right)$leaching. Leaching on the column was carried out under the pulse of urea-ammonium nitrate fertilizer (UAN 32) with a total concentration of $N 443 \mathrm{mg}-\mathrm{N} / \mathrm{L}$ $\left(\mathrm{NH}_{4}^{+}\right.$concentration $\left.37 \mathrm{mg}-\mathrm{N} / \mathrm{L}\right)$ for four soil treatments. The treatment consisted of $100 \%$ clinoptilolite zeolite (CZ), 100\% loamy sand (LS), a mixture of $80: 20 \%$ (LS:CZ) and a mixture of 60:40\% (LS:CZ) by weight. Of the total $\mathrm{NH}_{4}^{+}-\mathrm{N}$ pulse applied, only $3 \%$ were leached from the column of pure zeolite clinoptilolite compared with $17 \%$ in the loam sand column. An average $82 \%$ reduction in leaching was observed. It is also noted that leaching and retention of $\mathrm{NH}_{4}^{+}$in the treatment of loam sands by clinoptilolite using mass ratios of 60:40 and 80:20 slightly deviate from pure zeolites. The results of the experiments showed an inverse relationship between the adsorption of $\mathrm{NO}_{3}^{-}-\mathrm{N}$ and the amount of $\mathrm{CZ}$ added to the soil caused by anion exclusion and the direct relationship between the adsorption of $\mathrm{NH}_{4}^{+}-\mathrm{N}$ and the amount of mixed $\mathrm{CZ}$ with LS due to the capture of $\mathrm{NH}_{4}^{+}-\mathrm{N}$ by $\mathrm{CZ}$ molecules. Therefore, it is recommended to use fertilizers which do not contain $\mathrm{NO}_{3}^{-}$to LS soils enhanced by zeolite to reduce the risk of leaching.

Zeolites are also widely used in conjunction with other materials to increase soil nutrient availability, plant growth, and yield [35, 36].

In a study [36] the use of the chabazite-rich Italian volcanic tuff Sorano (Grosseto) as a conditioner for soils and slow nutrient fertilizers in silky-clay and sandy soils was evaluated using batch and column experiments. The results of the column experiments were simulated to obtain physicochemical and hydraulic parameters representative of soils altered by $\mathrm{NH}_{4}^{+}$-enriched zeolites. Using synthetic rainwater as eluent, $\mathrm{NH}_{4}^{+}$was never detected in the aqueous phase of batches and columns. $\mathrm{NO}_{3}^{-}$and $\mathrm{PO}_{4}^{3-}$ were presented in high concentrations in batch tests and leached in column elution tests. $\mathrm{NO}_{3}^{-}$ showed very high concentrations at the beginning of elution, whereas $\mathrm{PO}_{4}^{3-}$ showed low concentrations and backward peaks in both altered soil columns. The rationale for the study is that inorganic soil improvers, which improve the physical and hydraulic properties of the soil, can minimize nutrient leaching. This study suggests that natural zeolites, in combination with pig manure, may be a viable option for delaying excess nutrient leaching in farmland.

The use of new methods that improve the groundwater storage and the soil nitrogen availability for plants, but limit its leaching, can help to improve the quality of the environment [37 - 39].

Irrigation of soil through urban wastewater, which are not handled properly, adversely affects the soil and its subsequent drainage water. The use of natural zeolite to reduce contamination of agricultural soils irrigated by treated urban wastewater is investigated in the work [37]. The effect of the deposition method, the dosage and the particle size of the natural zeolite were studied by electrical conductivity, $\mathrm{pH}$ change, concentrations of $\mathrm{Na}^{+}, \mathrm{Ca}^{2+}+\mathrm{Mg}^{2+}$ and nitrates contained in urban sewage by passing them through zeolite-filled soil columns. The results indicate that when the zeolite was added to the soil column, the $\mathrm{pH}$, electrical conductivity and $\mathrm{Na}^{+}$values at the outlet of the column increased, and the concentration of $\mathrm{Ca}^{2+}+\mathrm{Mg}^{2+}$ and nitrates decreased. The concentration of nitrate of the column columns in the control, mixed and layered zeolite soil was lower than in fresh sewage by $12.18,32.19$ and $54.90 \%$ respectively. Therefore, the use of natural zeolite in the soil by layer treatment is more effective in reducing pollutants carried to the depth of the soil. 
In [38], the effect of band application or fully mixed of clinoptilolite zeolites (up to $90 \mathrm{Mg} / \mathrm{ha}$ ) and urea fertilizers (224 kg-N/ha) with silky loamy soil on $\mathrm{N}$ dynamics was studied during 35 days of incubation study. The treatment corresponding to the equivalent of $224 \mathrm{~kg}$ of urea fertilizer per hectare was applied with the equivalent of $0.0,6.7,13.4$ or $20.2 \mathrm{Mg}$ of zeolite per hectare. All treatments were weighed and pre-mixed before use. For band application: $250 \mathrm{~g}$ of soil was placed in a $8 \mathrm{~cm}^{3}$ plastic pot, urea + zeolite was placed on the soil surface, and then another $250 \mathrm{~g}$ of soil was placed on top. For fully mixing: $500 \mathrm{~g}$ of soil was placed in a $3.78 \mathrm{~L}$ plastic bucket, urea + zeolite were added, completely stirred by hand, and then the mixture was placed in a pot. The pots were lined with a plastic substrate to prevent leaching, placed in a growth chamber at a temperature of $22^{\circ} \mathrm{C}$ and humidity of $30 \%$ and watered twice a week with reverse osmosis water to $80 \%$ of field capacity. Samples were taken from pots at 1, 4, 7, 14, 21, 28 and 35 days and analyzed for $\mathrm{NO}_{3}-\mathrm{N}$ and $\mathrm{NH}_{4}-\mathrm{N}$ content. Two additional greenhouse experiments were conducted with sand to check soil moisture and maize (Zea mays $\mathrm{L}$ ) growth.

Compared with band application, $\mathrm{NH}_{4}^{+}$was protected from nitrification in loamy soil by fully mixing with zeolite $(20.2 \mathrm{Mg} / \mathrm{ha})$. This was probably caused by an increase in cation exchange capacity and subsequent adsorption of $\mathrm{NH}_{4}^{+}$in the zeolite mineral lattice. Mixing zeolite with sand at $44.8 \mathrm{Mg} / \mathrm{ha}$ increased the soil moisture by $2.6 \%$ and $2.1 \%$ (by weight) compared to the use of band application of $44.8 \mathrm{Mg} / \mathrm{ha}$ or control, respectively. Overall, compared to band application, complete blending of up to $44.8 \mathrm{Mg}$ of zeolite per ha in sand improved the soil moisture content by $1.3 \%$. Higher water content in zeolite treated soil than in the untreated was also found in the auxiliary study. After 6 weeks of corn gain in altered soil, zeolite application at $22 \mathrm{Mg} / \mathrm{ha}$ seemed to increase the weight of corn. However, an increase in the zeolite rate of up to $90 \mathrm{Mg} / \mathrm{ha}$ caused a decrease in maize weight, probably caused by an increased content of $\mathrm{Na}$ zeolite (3\%) [38].

The work [39] investigated the feasibility of using a zeolite modified with surfactant (SMZ) compared to the use of clinoptilolite zeolite (CZ) to reduce nitrate leaching and increase corn yield. Also evaluated the effect of size ( $\mathrm{mm}$ and $\mathrm{nm})$ and application rate $(20 \mathrm{~g} / \mathrm{kg}$, equivalent to $9 \mathrm{t} / \mathrm{ha}$ and $60 \mathrm{~g} / \mathrm{kg}$, equivalent to $27 \mathrm{t} / \mathrm{ha}$ ) of $\mathrm{CZ}$ and SMZ on the leaching of nitrates and the response to crops. Using soil lysimeters, it was found that the maximum and average nitrate concentration in SMZ soil was significantly lower $(\mathrm{p}<0.05)$ than in $\mathrm{CZ}$ soil. The total $\mathrm{NO}_{3}^{-}-\mathrm{N}$ emissions from the $\mathrm{SMZ}$ and $\mathrm{CZ}$ variable lysimeters at a higher application rate $(60 \mathrm{~g} / \mathrm{kg})$ were approximately $26 \%$ and $22 \%$ lower, respectively, than the control system. Average grain yield, content of nitrogen in the grain, dry matter and $\mathrm{N}$ uptake were significantly higher at $\mathrm{CZ}$ application than at SMZ application. There was no significant effect due to the particle size of the two soil improvers. The results of the study indicate that plants may have a better reaction if zeolite rather than surfactant-modified zeolite is used as the fertilizer carrier, at application rate of $60 \mathrm{~g} / \mathrm{kg}$.

In work [13] the synthesis of clinoptilolite and montmorillonite and their modification by surfactants, namely solutions of hexadecyltrimethylammonium bromide $\left(\mathrm{CH}_{3}\left(\mathrm{CH}_{2}\right)_{15} \mathrm{~N}(\mathrm{Br})\left(\mathrm{CH}_{3}\right)_{3}\right.$, HDTMAB $)$ and dioctadecylmethylammonium bromide $\left(\left(\mathrm{CH}_{3}\left(\mathrm{CH}_{2}\left(\mathrm{CH}_{2}\right)\right)_{17}\right)_{2} \mathrm{~N}(\mathrm{Br})\left(\mathrm{CH}_{3}\right)_{2}\right.$, DODMAB $)$

respectively, for the removal of nitrates and obtaining the nitrogen fertilizer of prolonged action are presented. The starting materials for the synthesis of zeolites were tetraethoxysilane $\left(\left(\mathrm{C}_{2} \mathrm{H}_{5} \mathrm{O}\right)_{4} \mathrm{Si}\right)$, aluminum nitrate $\left(\mathrm{Al}\left(\mathrm{NO}_{3}\right)_{3}\right)$, potassium nitrate $\left(\mathrm{KNO}_{3}\right)$ and sodium hydroxide $(\mathrm{NaOH})$ as sources of silicon, aluminum, potassium and sodium, respectively. Clinoptilolite and montmorillonite were hydrothermally synthesized using a Teflon-lined stainless steel vessel in a preheated $(423 \mathrm{~K})$ air oven at autogenous pressure and static conditions for $72 \mathrm{~h}$. The washed samples $(200 \mathrm{mg})$ of clinoptilolite and montmorillonite were mixed with $100 \mathrm{ml}$ of solutions of HDTMAB and DODMAB respectively $(250,500,750$ and $1000 \mathrm{mg} / \mathrm{L})$ prepared in a ratio of 1:1 (v/v) ethanol:deionized aqueous solution. An aqueous-alcoholic solution was used to improve the solubility of surfactants in water. The resulting suspensions were shaken at room temperature for $24 \mathrm{~h}$, then centrifuged and washed with ethanol: deionized aqueous solution (50:50). The X-ray diffraction patterns of the synthesized compounds are shown in Fig. 3 [13]. As can be seen from Fig. 3, X-ray diffractograms of clinoptilolite and montmorillonite are similar to their surfactant-modified forms, which indicates the structural integrity of the material before and after treatment with surfactants. The anion-exchange equilibrium between nitrate ions and bromide ions can be schematically written as follows [13]:

Zeolite-HDTMA-HDTMA-Br ${ }^{-}(\mathrm{s})+\mathrm{NO}_{3}{ }^{-}$(I) $\leftrightarrow$

$\leftrightarrow$ Zeolite-HDTMA-HDTMA-NO ${ }_{3}^{-}(\mathrm{s})+\mathrm{Br}^{-}(\mathrm{I})$

Zeolite-DODMA-DODMA- $\mathrm{Br}^{-}(\mathrm{s})+\mathrm{NO}_{3}{ }^{-}$(I) $\leftrightarrow$

$\leftrightarrow$ Zeolite-DODMA-DODMA-NO ${ }_{3}^{-}$(s) + $\mathrm{Br}^{-}$(I)

In an aqueous solution with a $\mathrm{NO}_{3}^{-}$concentration of 160 - $280 \mathrm{mg} / \mathrm{L}$, surfactant-modified zeolites exhibited significantly greater adsorption capacity than unmodified materials, which was determined by the Langmuir adsorption isotherms. The maximum adsorption capacity was $125 \mathrm{mg} / \mathrm{g}$ at $303 \mathrm{~K}$ for surfactant-modified clinoptilolite.

Slow-release studies of $\mathrm{NO}_{3}^{-}$were performed using a thin-layer funnel analytical test and a soil impregnation system (Fig. 4) [13]. According to the funnel analytical test, unmodified zeolite released $25-35 \% \mathrm{NO}_{3}^{-}$after the first irrigation, and modified only $15-20 \%$. In addition, on the first day of the column study, $\mathrm{NO}_{3}^{-}$desorption was $61 \%, 30-35 \%$ and less than $18 \%$ in soil, clinoptilolite and modified surfactant clinoptilolite, respectively. Even after 15-20 days of leaching, surfactant-modified zeolites still released $\mathrm{NO}_{3}^{-}$, which clearly indicates that slow release of $\mathrm{N}$ into the soil is achieved by the application of this type of modified zeolite [13].

In [40], the absorption of nitrate $\left(\mathrm{NO}_{3}^{-}\right)$and ammonium $\left(\mathrm{NH}_{4}^{+}\right)$ions from environmentally friendly materials suitable for the purification of contaminated 


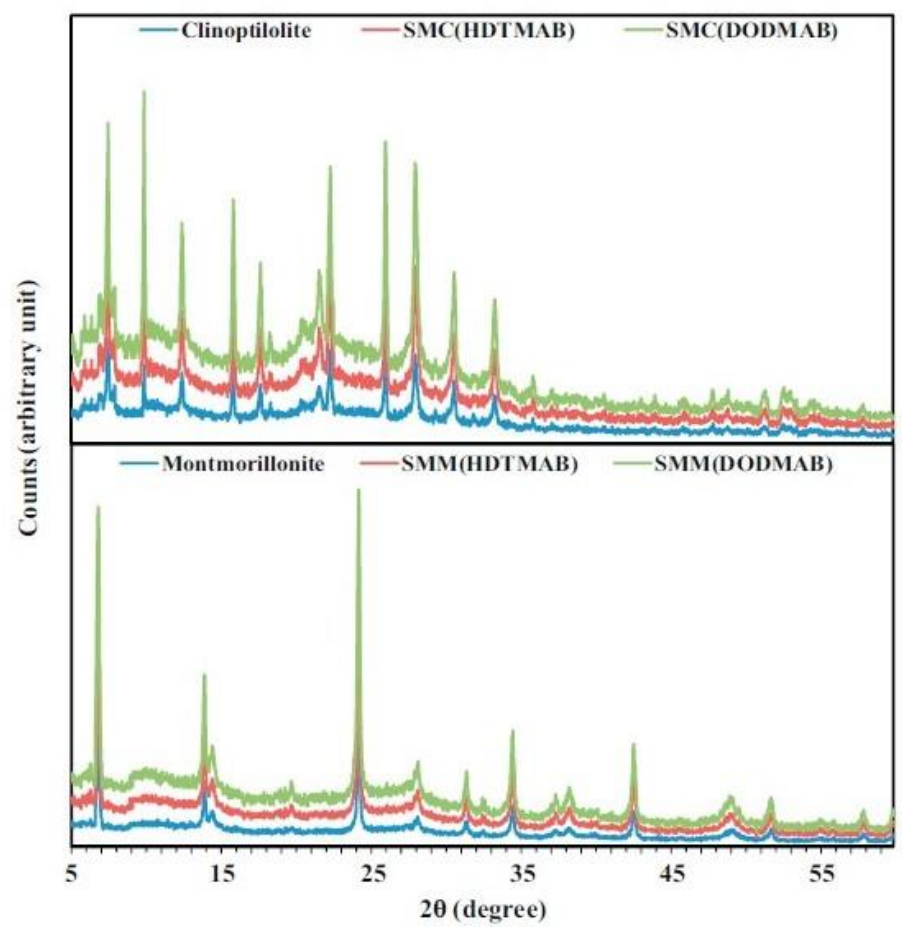

Fig. 3. X-ray diffraction patterns of raw clinoptilolite and montmorillonite and their modified forms [13].
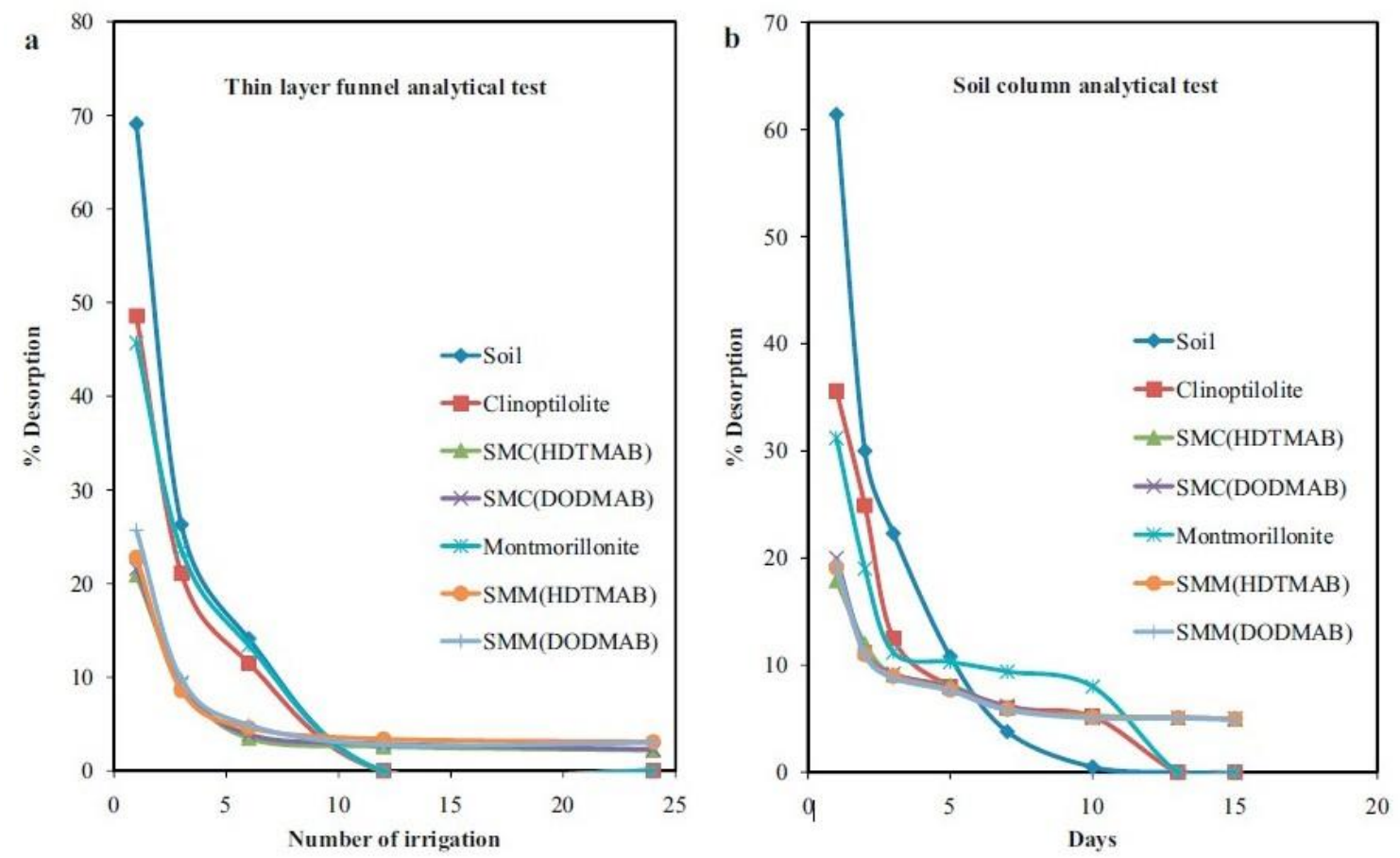

Fig. 4. Study of $\mathrm{NO}_{3}^{-}$leaching using unmodified and modified zeolites: thin-layer funnels-analytical test (a); soil column-analytical test (b) (303 K, deionized water as leachate) [13].

water and soil is studied. Materials such as zeolite $(\mathrm{Z})$, goethite $(\mathrm{G})$, modified zeolite I (Z-G I), and modified zeolite II (Z-G II) were used either as adsorbents for aqueous solutions or as soil improvers. The studies consisted of two parts: laboratory and greenhouse experiments. Absorption of $\mathrm{NO}_{3}^{-}$and $\mathrm{NH}_{4}^{+}$ions in aqueous solutions from adsorbents was studied by laboratory experiments. Eight initial concentrations of
$\mathrm{NO}_{3}^{-}(5,10,30,50,100,150,200$ and $300 \mathrm{mg} \mathrm{NO}-\mathrm{L})$ and seven initial concentrations of $\mathrm{NH}_{4}^{+}(1,5,50,100$,

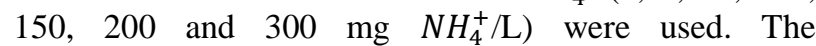
experimental data were consistent with the Langmuir, Freundlich and Temkin isotherm models. The results showed that the modification of zeolite with goethite led to a positively charged modified zeolite surface $\left(\mathrm{pH}_{\text {z.p.c. }}(\mathrm{Z}-\mathrm{G} \quad \mathrm{I})=8.54, \quad \mathrm{pH}_{\text {z.p.c. }}(\mathrm{Z}-\mathrm{G} \quad \mathrm{II})=9.19\right)$ for 
absorption of $\mathrm{NO}_{3}^{-}$ions with a $\mathrm{pH}$ of 8.26 for $\mathrm{ZG} \mathrm{I}$ and 8.92 for ZG II, and a negatively charged modified zeolite surface for absorption of $\mathrm{NH}_{4}^{+}$ions with a $\mathrm{pH}$ of 8.60 for Z-G I and 9.40 for Z-G II. The increase in the adsorption capacity of $\mathrm{NO}_{3}^{-}$ions is in the order: Z-G II> Z-G I> $\mathrm{G}>\mathrm{Z}$, while the adsorption capacity of $\mathrm{NH}_{4}^{+}$ions is increased as follows: Z> Z-G I> G> Z-G II.

The efficiency of soil improvers for the retention of $\mathrm{NO}_{3}^{-}$and $\mathrm{NH}_{4}^{+}$ions in wheat (Triticum durum) was studied by greenhouse experiments. Used two doses of nitrogen (300 and $600 \mathrm{~kg}-\mathrm{N} / \mathrm{ha})$ in the form of $\mathrm{NH}_{4} \mathrm{NO}_{3}$, conducted 33 treatments (24 with soil enhancers, 6 without soil enhancers and 3 without soil enhancers and nitrate ions). The results showed that $\mathrm{Z}$ adsorbed the highest amount of $\mathrm{NH}_{4}^{+}$ions, whereas Z-G II adsorbed the highest amount of $\mathrm{NO}_{3}^{-}$ions. On soil with wheat, the results showed that soil improvers reduced the concentration of nitrate and ammonium ions in the soil and simultaneously nitrate nitrogen in plants [40].

Adding zeolite to the soil can reduce $\mathrm{NO}_{3}^{-}$leaching due to its unique physicochemical properties. This makes $\mathrm{NH}_{4}^{+}$inaccessible to nitrobacteria. In [41], the use of natural zeolite to reduce nitrogen leaching and increasing the yield of fodder rape was investigated. $\mathrm{NO}_{3}^{-}$leaching was monitored after application of urea fertilizer into the soil on three levels of $\mathrm{N}(90,180$ and $270 \mathrm{~kg}-\mathrm{N} / \mathrm{ha})$ and clinoptilolite according to four standards $(0,3,6$ and $9 \mathrm{t}$ of zeolite per hectare). Minimum leaching of $\mathrm{NO}_{3}^{-}$was obtained at a higher rate of zeolite application ( 9 tonnes of zeolite per hectare). Compared to the control sand, this treatment resulted in a 36 and $37 \%$ reduction in $\mathrm{NO}_{3}^{-}$ leaching losses in the first and second years, respectively. Although the concentration of $\mathrm{N}$ in feed decreased with the simultaneous use of zeolite, the quality of forage rape crop and its quantity did not decrease.

\subsection{Zeolite-based phosphorus fertilizers}

\subsubsection{The role of phosphorus for plant growth}

Plants absorb much less phosphorus than nitrogen, but it plays an extremely important role in their lives. Its content in plants is $0.5-1 \%$ of dry matter, in particular mineral compounds account for about $10-15 \%$, organic $-85-90 \%$. The ratio of mineral and organic compounds of phosphorus depends on the age of the plants and general phosphorus supply. In young plants, the proportion of organic phosphorus is much higher than in old ones. Phosphates of calcium, magnesium, potassium, ammonium, etc. represent mineral compounds of phosphorus in plants. Their accumulation in the stems of plants is a sign of high availability of plants with phosphorus. Organic phosphorus compounds are esters of phosphoric acid. These include phosphatides, phosphoproteins, phytin, sugar phosphates, nucleic acids, nucleoproteins, and other compounds [27, 28].

The maximum amount of phosphorus is contained in the reproductive organs. It also contributes to the rapid formation of the root system of plants. In this case, the plants absorb water and nutrients from the soil better, rather from an aboveground mass. The bulk of phosphorus is used by plants in the first stages of growth and development, creating matching stocks. Then phosphorus is easily moved from the old tissues in the young, that is, its reutilization. Excessive supply of phosphorus leads to premature development and dying of the leaf apparatus, early reaching of the fruits, resulting in plants do not have time to form a proper crop. Phosphorus deficiency manifests itself in retardation of plant growth and development - small leaves are formed, delayed flowering and fruiting [27, 28].

The main source of plant nutrition for phosphorus is anions of orthophosphoric acid $-\mathrm{H}_{2} \mathrm{PO}_{4}^{-}, \mathrm{HPO}_{4}^{2-}, \mathrm{PO}_{4}^{3-}$, but plants can partially absorb poly- and metaphosphates and some organic phosphorus compounds. They best absorb $\mathrm{H}_{2} \mathrm{PO}_{4}^{-}$anions, worse $-\mathrm{HPO}_{4}^{2-}$ anions. $\mathrm{PO}_{4}^{3-}$ anions are inaccessible to plants. The level of absorption of phosphorus by plants depends not only on its content in the soil, but also on the availability of other nutrients. Due to the lack of zinc, the supply and use of phosphorus is reduced by plants, and in the case of high copper supply, on the contrary, the need for phosphorus is reduced $[27,28]$.

Raw materials for industrial production of phosphorus fertilizers are natural deposits of phosphorus ores - apatites and phosphorites. Increasing the release of phosphorus fertilizers is a complex technological task, where the main is the conversion of phosphorus compounds into soluble state. Natural phosphates are processed by three basic chemical methods, the most common of which is the decomposition of phosphates by acids - sulphuric, orthophosphoric, nitric, etc. For acid decomposition are suitable natural phosphates which do not contain significant amounts of calcium carbonate, carbonates and silicates of magnesium, iron and aluminum compounds (these and other impurities complicate the processing of phosphates) [27, 28].

3.2.2. Influence of zeolites on retention and release of phosphorus fertilizers into the soil

Zeolites are aluminosilicate minerals with a small amount of iron and aluminum hydroxides. They have a large negatively charged surface and lack of anion exchange capacity. Therefore, the addition of zeolite to the soil does not significantly affect the leaching of $\mathrm{PO}_{4}^{3-}$. The use of zeolites as a prolonged action fertilizer is limited by cationic nutrients that can be loaded into zeolite positions $\left(\mathrm{NH}_{4}^{+}\right.$and $\left.\mathrm{K}^{+}\right)$. Therefore, the loading of anionic nutrients such as $\mathrm{PO}_{4}^{3-}$ is negligible for unmodified zeolites. However, several studies have shown that the controlled and gradual release of $\mathrm{PO}_{4}^{3-}$ is achieved by a combination of ion-exchange zeolite and mineral dissolution [2, 42, 43].

The work [42] investigates the release of nutrients from a zeolite substrate containing phosphate waste. The combination of zeolites with phosphate materials (zeoponic substrate) is consistent with the gradual and controlled release of phosphorus into the soil: phosphorus for plant absorption is released by combining dissolution and ion exchange reactions [42]:

$$
\begin{gathered}
\frac{1}{2} \mathrm{Ca}_{5}\left(\mathrm{PO}_{4}\right)_{3} \mathrm{~F}+\frac{3}{2} \mathrm{H}_{2} \mathrm{O} \leftrightarrow \frac{5}{2} \mathrm{Ca}^{2+}+\frac{3}{2} \mathrm{HPO}_{4}^{2-}+\frac{1}{2} \mathrm{~F}^{-}+\frac{3}{2} \mathrm{OH}^{-} ; \\
\frac{1}{2} \mathrm{Ca}^{2+}+\mathrm{NH}_{4}^{+} \text {-zeolite } \leftrightarrow \mathrm{NH}_{4}^{+}+\frac{1}{2} \mathrm{Ca}^{2+} \text {-zeolite} ; \\
\frac{1}{2} \mathrm{Ca}^{2+}+\mathrm{K}^{+} \text {-zeolite } \leftrightarrow \mathrm{K}^{+}+\frac{1}{2} \mathrm{Ca}^{2+} \text {-zeolite }
\end{gathered}
$$


where $\mathrm{Ca}_{5}\left(\mathrm{PO}_{4}\right)_{3} \mathrm{~F}$ is fluorapatite, a constant source of phosphorus; $\mathrm{K}^{+}-$zeolite - potassium enriched zeolite; $\mathrm{NH}_{4}^{+}$- zeolite - exchange zeolite with ammonium ions. The first reaction shows a weak dissolution of mountain phosphate. In the second and third reactions, due to the high cation exchange capacity of the zeolites, calcium is adsorbed on the zeolite surface. This system releases $\mathrm{PO}_{4}^{3-}, \mathrm{NH}_{4}^{+}$and $\mathrm{K}^{+}$ions. Thus, the absorption of nutrients by plant roots continues.

The ash of animal bones, which is rich in phosphorus and is leached alone, releases a small amount of soluble phosphorus and a lot of alkaline sodium and potassium. With respect to habazite zeolite, it supports the gradual and increasing release of phosphorus from the ashes of the bones of animals, in accordance with the ability of clinoptiloliticzeolitites and phillipsiticzeolitites. In particular, this release is enhanced by the increased zeolite/bone ash ratio and the ammonium enriched zeolite [42].

Leaching of a mixture of natural zeolite and bone ash was repeated three times, changing the ratio of zeolite/bone ash. In particular, the ratio increased in stages and was $1: 1,2: 1$ and 3:1. Leaching of a mixture of ammonium exchange zeolite and bone ash was also repeated three times with the same ratio. Enrichment with ammonium consisted of a leaching process: the zeolite was eluted with a $1 \mathrm{M}$ ammonium chloride solution. The content of the dried ammonium powder, as measured by thermogravimetric analysis, was approximately $0.91 \mathrm{mg}$-eq/g. On all samples after leaching of a particular solid mixture, the total amount of $\mathrm{P}, \mathrm{Na}, \mathrm{K}$ and $\mathrm{pH}$ was determined to simulate soil water runoff. The $100 \mathrm{~g}$ solid phase was eluted with deionized water, each treatment consisted of ten impregnations: each sample, volume of solution $100 \mathrm{ml}$, was collected after 50 minutes [42].

Hypothetically, the utilization of the zeoponic substrate can be successful for many reasons, both environmental and social. Regarding the environmental benefits, firstly, these systems contribute to the gradual and free release of phosphorus and the reduction of synthetic fertilizer production: zeoponic substrates with $\mathrm{N}$ and $\mathrm{K}$ deficiency can be mixed with traditional fertilizer formulations, limiting their production and use. In addition, the benefits of the 'zeolite/animal bones ashes' system in the supply of nutrients, compared to standard soluble fertilizer, are the chemical resistance of zeolite in soils, its ability to retain water and the resistance of $\mathrm{NH}_{4}^{+}$in zeolite to leaching and microbial attack. Chabazite can be enriched with $\mathrm{NH}_{4}^{+}$by the method of impregnation with ammonium salts, and the content of ammonium in the zeolite can be the result of removal of ammonium from wastewater. In addition, zeoponic substrate promotes the processing of ash formed from animal bones: if these powders are mixed with zeolite, they will be optimized and removed from the waste stream, avoiding their landfills [42].

Ammonium-exchange clinoptilolite (zeolite) with rock phosphate (rock phosphate - RP) is known to accelerate the RP dissolution process and enhance plant growth reactions; however, the mechanism underlying the accelerated dissolution of RP remains unclear. In [43], the authors investigate the acidic dissolution of mountain phosphate upon binding to ammonium zeolite on sunflowers. A total of 14 combinations were studied, namely: P-source (mountain phosphate or tricalcium phosphate), placement (band or scattered treatment), zeolite (untreated or exchangeable with $\mathrm{NH}_{4}, \mathrm{~K}$ or $\mathrm{Ca}$ ), and also plants in one-liter pots containing peat and perlite were installed. Sunflower (Helianthus annuus L.) growth was greatest after 27 days of band and scattered orthophosphate treatment, however, mountain phosphate treated with ammonium zeolite gave $20 \%$ less total leaf length. $\mathrm{pH}$ of the soil solution in $\mathrm{RP}$ and ammonium zeolite bands decreased by two units simultaneously with a very significant fourfold increase in the concentration of $\mathrm{P}$ in solution. Root growth was spread in RP and ammonium zeolite bands. Sunflower growth was very slow in all other RP processing methods with a slight change in $\mathrm{pH}$ or concentration of $\mathrm{P}$ in solution. The results of this study indicate that the dissolution of $\mathrm{P}$ from rock phosphate together with $\mathrm{NH}_{4}^{+}$exchange zeolite was initiated by the release of protons from plant roots after $\mathrm{NH}_{4}^{+}$absorption (plant-managed process).

The possibility of using surfactant-modified zeolite (SMZ) as a carrier for phosphorus (P) slow-release fertilizers (SRFs) was investigated in [44]. Zeolite-A was modified with hexadecyltrimethylammonium bromide (HDTMABr), a cationic surfactant to increase its ability to retain phosphate anion $\left(\mathrm{PO}_{4}^{3-}\right)$. Pre-weighed amount of the washed zeolite sample was mixed with a solution of HDTMABr in a ratio of 1:100 (wt.). The concentrations of HDTMABr solutions used for the preparation of SMZ-1, SMZ-2, SMZ-3 were 50, 100 and $200 \mathrm{mg} / \mathrm{L}$, respectively. The solution was stirred for 7-8 hours at $150 \mathrm{rpm}$. Filtered, washed with double-distilled water, dried for 4-6 hours. The synthesized SMZ was ground in a mortar to a fine particle size. SRFs with different surfactant loading $(1.7 ; 3.8$ and $4.6 \mathrm{mg} / \mathrm{g}$ zeolite) were treated with $\mathrm{KH}_{2} \mathrm{PO}_{4}$ to obtain nutrientloaded SRFs. To study the sorption behavior of phosphate on different zeolites, different amounts of zeolite were added to centrifuge tubes to $50 \mathrm{~mL}$ of $\mathrm{KH}_{2} \mathrm{PO}_{4}$ solution in centrifuge tubes. The mixture was stirred for $12 \mathrm{~h}$ at $150 \mathrm{rpm}$ and centrifuged. The concentration of the phosphate solution was analyzed by the addition of ammonium orthomolybdate and tin chloride (a blue-colored complex was formed). Absorption was measured at $690 \mathrm{~nm}$ with a UV-visible spectrophotometer. The amount of adsorbed phosphate was calculated from the difference between the initial and equilibrium concentrations of the solution. To obtain SRFs, the required amount of SMZ was mixed with a 1.0 $\mathrm{M} \mathrm{KH} \mathrm{H}_{2} \mathrm{PO}_{4}$ solution for 8 hours, filtered, washed three times with deionized water and air-dried. For the synthesis of P-loaded zeolites, the ratio was 1:10 (wt.). Nutrients were similarly loaded onto unmodified zeolite to study the effect of surface modification on nutrient uptake and slow release compared to SMZ. The amount of adsorbed $\mathrm{PO}_{4}^{3-}$ was calculated from the difference between the initial and equilibrium concentrations of the solution. To study the effects of SMZ modification, they were carefully characterized by XRD, FTIR, and SEM. IR spectra confirmed the structural stability of the zeolite after modification by a surfactant. In addition, the presence of HDTMABr peaks in the SMZ IR spectra 


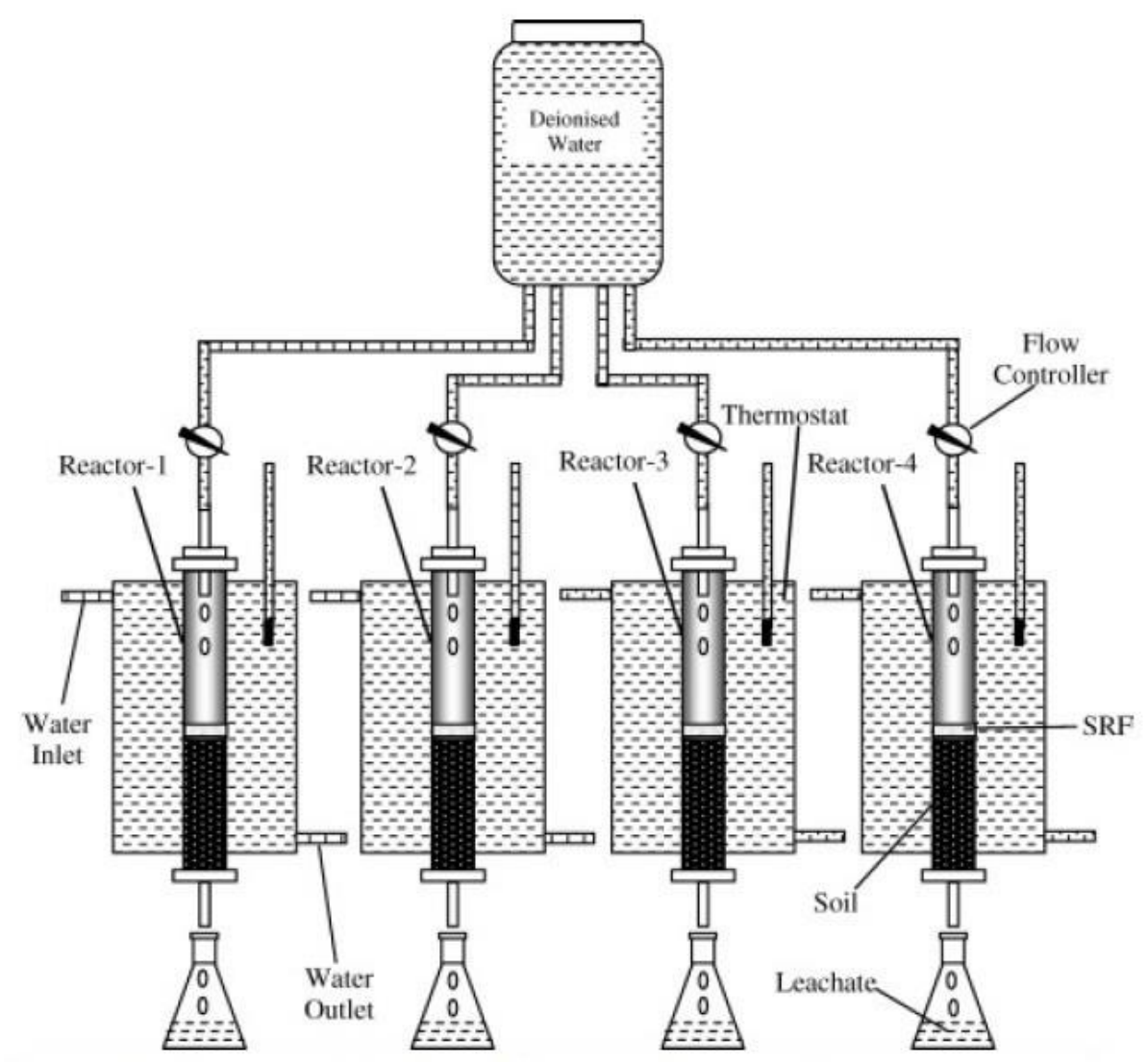

Fig. 5. Experimental setup of the percolation reactor for nutrient uptake [44].

indicate HDTMABr sorption on the zeolite surface. SEM analysis was performed to investigate the morphology of the SMZ surface. A comparative study of phosphorus release from fertilizer-loaded unmodified zeolite-A and $\mathrm{SMZ}$ and from solid $\mathrm{KH}_{2} \mathrm{PO}_{4}$ was performed using a percolating DC reactor (Fig. 5) [44]. The results show that the supply of phosphorus from SMZ loaded with fertilizers was available even after 1080 hours of continuous impregnation, whereas phosphorus from $\mathrm{KH}_{2} \mathrm{PO}_{4}$ was depleted within 264 hours. The results indicate that SMZ is a good sorbent for $\mathrm{PO}_{4}^{3-}$ and the slow release of phosphorus has been successfully achieved. These properties show that SMZ has great potential as a fertilizer carrier for the slow release of phosphorus [44].

In [45], the adsorption-desorption of phosphorus on surfactant-modified zeolite (SMZ) was studied by means of laboratory experiments in terms of using SMZ to remove $\mathrm{P}$ from phosphorus-enriched waters. The effects of temperature, $\mathrm{pH}$, and $\mathrm{NO}_{3}^{-}$concentration on $\mathrm{P}$ adsorption on SMZ were evaluated. Natural zeolite clinoptilolite with chemical formula $\left(\mathrm{Ca}_{1.5} \mathrm{~K}_{1.4} \mathrm{Mg}_{0.6} \mathrm{Na}_{0.5}\right)\left(\mathrm{Al}_{6.2} \mathrm{Si}_{29.8} \mathrm{O}_{72}\right) \cdot 20 \mathrm{H}_{2} \mathrm{O}$

(composition was determined by TXRD) was used for the study. The zeolite was sieved through a $2 \mathrm{~mm}$ stainless steel sieve, cation exchange ability was determined by Ming and Dixon method (226 and 10 $\mathrm{s} \cdot \mathrm{mol} / \mathrm{kg}$, respectively). Modification of the surface of the zeolite was carried out using hexadecyltrimethylammonium bromide $\left(\mathrm{C}_{19} \mathrm{H}_{42} \mathrm{BrN}\right.$ or
HDTMA-Br). The zeolite was mixed with 0.05 HDTMA-Br for 24 hours at $25^{\circ} \mathrm{C}$ with periodic shaking (the ratio of surfactants to zeolite $4: 1(\mathrm{v} / \mathrm{w})$ ). Centrifuged at $7000 \mathrm{rpm}$ for 5 minutes. Washed three times with distilled water and air-dried. $4 \mathrm{~g}$ of samples (three replicates) were placed in $50 \mathrm{ml}$ polypropylene centrifuge tubes with $40 \mathrm{ml}$ of deionized water containing different concentrations of $\mathrm{P}(0,0.5,1,2,5,8$, $10,12,15,20,30,40,50 \mathrm{mg} / \mathrm{L})$ as $K_{2} \mathrm{PO}_{4}$. The suspensions were equilibrated for 1 hour at $25^{\circ} \mathrm{C}$ with shaking. Then it was centrifuged and the supernatant was filtered and analyzed for $\mathrm{P}$ using ascorbic acid and UVvisible spectrophotometry. The amount of adsorbed $\mathrm{P}$ was calculated from the difference between the added amount and the one in solution at equilibrium.

The adsorption data indicated that SMZ has a high adsorption capacity for phosphorus and satisfactorily corresponds to the nonlinear forms of the Freundlich and Langmuir equations, the latter being somewhat higher. Phosphorus adsorption on SMZ was a rapid exothermic reaction. With increasing $\mathrm{pH}$ of the equilibrium solution (from acidic to alkaline) phosphorus adsorption also increased. In the presence of $\mathrm{NO}_{3}^{-}$in the external solution, adsorption $\mathrm{P}$ was reduced only at the highest $\mathrm{NO}_{3}^{-}$concentration tested $(50 \mathrm{mg} / \mathrm{L})$. Given the high availability of zeolite, its low cost and the simplicity of the techniques that can be used to modify its surface, it has been concluded that surfactant-modified zeolite can be an effective phosphorus adsorbent and can be used to remove it from enriched $\mathrm{P}$ waters; however, the latter 
should be confirmed by large-scale experiments [45].

The influence of zeolite and phosphorus application on water use, water supply and rice yield under irrigation is investigated in [46]. Conducted a two-year lysimeter experiment using a split plot to investigate the effect of zeolite ( 0 or $15 \mathrm{t} / \mathrm{ha}$ ) and $\mathrm{P}$ ( 0 or $60 \mathrm{~kg} / \mathrm{ha}$ ) on water use, $\mathrm{P}$ uptake, and rice grain yield under two irrigation management systems (continuous) irrigation and improved alternate wetting and drying). Conducted a two-year lysimeter experiment using a split plot to investigate the effect of zeolite ( 0 or $15 \mathrm{t} / \mathrm{ha})$ and $\mathrm{P}(0$ or $60 \mathrm{~kg} / \mathrm{ha}$ ) on water use, $\mathrm{P}$ uptake, and grain yield in rice by two irrigation management systems (continuous irrigation and improved alternate wetting and drying). The use of zeolite or P only increased the grain yield, the presence of $\mathrm{P}$ in the soil, the concentration of phosphorus in the stems, leaves and aboveground P-absorption, but had no significant effect of using water. The use of zeolite increased $\mathrm{NH}_{4}^{+}-\mathrm{N}$ retention in the upper soil and prevented $\mathrm{NO}_{3}^{-}-\mathrm{N}$ leaching into deeper soil layers. Moreover, zeolite has reduced the possible rates of $\mathrm{P}$ fertilizers in rice fields, with an advantage for residues of P-stocks and reduced pollution due to excess phosphorus.

\subsection{Zeolite-based potassium fertilizers}

\subsubsection{The role of potassium for plant growth}

Plants usually accumulate more potassium compared to nitrogen and phosphorus. In the process of plant growth and development, it moves from old organs and tissues to young growing organs where it is reused. Therefore, the content of potassium in vegetative organs is always higher than in seeds, tubers and root crops, except for legumes. Thus, the leaves of potatoes, sunflower and sugar beet contain $4-6 \%$ of potassium, in cereal straw $-1-1.5 \%$, in cabbage - up to $0.5 \%$, whereas in cereal seeds it is about $0.5 \%$, in root crops $-0.3-0.6 \%$ $[27,28]$.

Potassium in plants is actively involved in protein and carbohydrate metabolism, activates the activity of enzymes, regulates the processes of opening and closing of breaths on the leaves, absorption of moisture by the root system, which promotes the rational and efficient use of water. Therefore, the availability of potassium in plants increases their resistance to drought, adverse effects of high and low temperatures. Plants become more frost-resistant under the influence of potassium, which is associated with an increase in sugar content in cells and an increase in osmotic pressure. In addition, potassium has a positive effect on the taste of the fruits. Potassium deficiency inhibits some biochemical processes in the plant, which negatively affects the metabolism. Magnesium starvation of plants is observed due to excess potassium in the soil $[27,28]$.

Raw materials for the production of potash fertilizers are natural deposits of potassium salts $\left(\mathrm{KCl}, \mathrm{K}_{2} \mathrm{SO}_{4}\right.$, $\mathrm{KCl} \cdot \mathrm{MgSO}_{4} \cdot 3 \mathrm{H}_{2} \mathrm{O}$, etc.) and brine of salt lakes. The water of oceans and seas contains about $0.05 \%$ of potassium, so seawater can be an inexhaustible source for the industrial production of potassium salts.

3.3.2. Influence of zeolites on retention and release of potassium fertilizers into the soil

Zeolite minerals have a pronounced selectivity for $\mathrm{K}^{+}$compared to other ions such as $\mathrm{NH}_{4}^{+}, \mathrm{Na}^{+}, \mathrm{Ca}^{2+}$ and
$\mathrm{Mg}^{2+}$. Therefore, it is difficult to remove $K^{+}$from the zeolite exchange positions with these less selective cations. It is known that the cation exchange capacity of the zeolite obtained using solutions of $1 \mathrm{M} \mathrm{KCl}$ and $1 \mathrm{M}$ $\mathrm{NH}_{4} \mathrm{Cl}$ was significantly higher than the values obtained using solutions of $0.1 \mathrm{M} \mathrm{BaCl}$ and $0.1 \mathrm{M} \mathrm{BaCl} / \mathrm{NH}_{4} \mathrm{Cl}$. The use of zeolite as a prolonged $K^{+}$-fertilizer results in reduced $K^{+}$leaching to runoff and groundwater [2].

In [47] investigated the effect of zeolite application on $K^{+}$release in sandy soils supplemented with municipal compost. Three sample mixtures were prepared: soil/compost (SC), soil/compost/zeolite (SCZ) and zeolite/compost (ZC). All samples were sieved (below $2 \mathrm{~mm}$ ) before use and dried at $40^{\circ} \mathrm{C}$. The application rate of SC was $200 \mathrm{t} / \mathrm{ha}$ of dry weight ( $90.6 \%$ (w/w) of soil and $9.4 \%$ (w/w) of compost). The SCZ sample was obtained by mixing SC with $30 \%$ (w/w) zeolite, whereas the ZC sample contained $90.6 \%$ $(\mathrm{w} / \mathrm{w})$ zeolite and $9.4 \%(\mathrm{w} / \mathrm{w})$ compost. $30 \%(\mathrm{w} / \mathrm{w})$ ratio of zeolite to SC sample was selected to enhance the effect of zeolite addition and to evaluate this effect. Because the zeolite was not homo-ionized, it was expected that the adsorption capacity would be reduced, which was a decisive factor for selecting a high dose of zeolite to enhance the adsorption effect of the zeolite. The ZC sample was specially prepared to investigate the direct interaction of zeolite with compost and compare it with the SC sample. $\mathrm{pH}$ and electrical conductivity were determined using a $\mathrm{pH}$ conductometer (WTW, 340i) in a mixture of soil supernatant: deionized water 1:2. Cation exchange ability was calculated by ammonium acetate method by adjusting the $\mathrm{pH}$ at 7 . Kinetic experiments have shown that the addition of zeolite to soil-compost mixtures does not affect the potassium desorption. At the same time, this leads to an 18-fold increase in bioavailable potassium. Column tests have shown that the amount of potassium leaching is reduced six times by the use of zeolite. The experimental results indicate a high affinity of potassium to soil/compost/zeolite (SCZ) at $\mathrm{pH}>7$.

\subsection{Zeolite-based complex fertilizers}

In addition to one-sided mineral fertilizers containing only one basic nutrient (nitrogen, phosphorus or potassium), the fertilizers industry also produces complex mineral fertilizers. These can be either single salts with different elements for plant nutrition, for example, $\mathrm{KNO}_{3},\left(\mathrm{NH}_{4}\right)_{2} \mathrm{HPO}_{4}$, and their compositions of two $(\mathrm{N}+\mathrm{P}, \mathrm{N}+\mathrm{K}, \mathrm{P}+\mathrm{K})$ or three $(\mathrm{N}+\mathrm{P}+\mathrm{K})$ elements. Such compositions are obtained by the interaction of nitric, orthophosphate and sulfate acids with ammonia, natural phosphates, potassium and ammonium salts. The higher the total content of the active substance in the fertilizer, the more valuable it is. In addition, the fertilizer may include sulfur, magnesium, trace elements. The production of complex fertilizers is economically advantageous, since in practice more than one nutrient is introduced at a time, while the separate application of each fertilizer requires additional costs [27, 28].

In [48], the authors investigate the use of complex nitrogen, phosphorus and potassium fertilizers using clinoptilolite zeolite in corn cultivation. Experiments were conducted in pots with complex $\mathrm{N}: \mathrm{P}: \mathrm{K}$ fertilizers: 
$14.88 \mathrm{~g}$ of commercial compound fertilizer with a ratio of 15:15:15 (control) (T1); complex fertilizer with a ratio of $15: 15: 15 \quad(4.85 \mathrm{~g}$ of urea $+4.85 \mathrm{~g}$ of triple superphosphate $+3.72 \mathrm{~g}$ of potassium muriate) mixed with $1.46 \mathrm{~g}$ of clinoptilolite zeolite (T2); complex fertilizer with a ratio of 13:15:13 (4.85 g of urea $+5.61 \mathrm{~g}$ of triple superphosphate $+3.73 \mathrm{~g}$ of potassium muriate) mixed with $3.01 \mathrm{~g}$ of clinoptilolite zeolite (T3); complex fertilizer with a ratio of 10:10:10 (4.85 $\mathrm{g}$ of urea $+4.85 \mathrm{~g}$ of triple superphosphate $+3.73 \mathrm{~g}$ of potassium muriate) mixed with $8.92 \mathrm{~g}$ of clinoptilolite zeolite (T4); complex fertilizer with a ratio of 8:8:8 (4.85 $\mathrm{g}$ of urea $+4.85 \mathrm{~g}$ of triple superphosphate $+3.71 \mathrm{~g}$ of potassium muriate) mixed with $14.46 \mathrm{~g}$ of clinoptilolite zeolite (T5); complex fertilizer with a ratio of 5.5:5.5:5.5 (4.85 $\mathrm{g}$ of urea $+4.85 \mathrm{~g}$ of triple superphosphate $+3.72 \mathrm{~g}$ of potassium muriate) mixed with $27.04 \mathrm{~g}$ of clinoptilolite zeolite (T6); only soil (control) (T7).

The effect of T1, T3 and T6 on total nitrogen content in soil is found to be significant compared to T7. The treatment with clinoptilolite for phosphorus and potassium content in the soil and available phosphorus and potassium was significantly different from $\mathrm{T} 1$ and T7. T5 and T6 treatments had the highest accumulation of exchange $\mathrm{NH}_{4}^{+}$and available $\mathrm{NO}_{3}^{-}$relative to T1 and T7. It has been found that soil treatment with clinoptilolite-based fertilizer has a significant effect on the concentration, efficiency of nitrogen uptake and utilization and can reduce $\mathrm{NH}_{3}$ loss, causing $\mathrm{NH}_{4}^{+}$and $\mathrm{NO}_{3}^{-}$formation over ammonia, and increase the absorption by corn. Regarding the concentration, efficiency of absorption and use of phosphorus, it was found that in most treatments with clinoptilolite lower values were obtained relative to commercial fertilizers, although treatment with zeolite clearly improves the phosphorus absorption by roots. In terms of concentration, efficiency of absorption and use of potassium, most treatments with zeolite remained statistically similar compared to commercial fertilizers [48]. Consequently, treatment with a higher amount of clinoptilolite showed the highest accumulation of exchangeable $\mathrm{NH}_{4}^{+}$and available $\mathrm{NO}_{3}^{-}$compared to commercial fertilizer. Most treatments with clinoptilolite had a similar effect on plant height, dry weight, N, P and $\mathrm{K}$ concentrations, absorption efficiency and use compared to commercial fertilizers.

In a study [49], the authors considered the effectiveness of NPK-organo-zeolite (NPKOZ) as a controlled release fertilizer for the growth of medicinal plants such as Centella asiatica. $40 \mathrm{~g}$ of zeolite was mixed with $\mathrm{KCl}$ overnight with a magnetic stirrer. Then the mixture was filtered with $185 \mathrm{~mm}$ Macherey-Nagel filter paper and dried in an oven at $80{ }^{\circ} \mathrm{C}$ overnight. Then the solid mesh was ground in a mortar into powder and sieved. The steps were repeated three times to ensure that most $\mathrm{K}$ ions were placed inside the zeolite frame to form K-zeo. Next, $10 \mathrm{~g}$ of K-zeo was mixed with $4 \mathrm{mM}$ HDTMA and after the grinding process received Organo$\mathrm{K}$-zeo (OKZ). Finally, $40 \mathrm{~g}$ of OKZ was added to the monoammonium phosphate to form the final product NPKOZ.
X-ray diffraction patterns of modified zeolite (K-zeo, OKZ, and NPKOZ) were compared with unmodified zeolite. It was found that composites consist of natural zeolite clinoptilolite and some quartz and mordenite impurities. A characteristic of the prepared materials by FTIR spectroscopy was performed to detect the presence of HDTMA molecules in the sample. Important bands were observed in FTIR spectra of surfactant-modified zeolite (OKZ) (2921 and $2850 \mathrm{~cm}^{-1}$ ) and NPKOZ (2923 and $\left.2851 \mathrm{~cm}^{-1}\right)$. These bands proved the presence of asymmetric $\mathrm{CH}_{3}$ and stretching the $\mathrm{CH}_{2}$ of HDTMA molecules, respectively. Peaks below $1000 \mathrm{~cm}^{-1}$ represent the $\mathrm{Si}-\mathrm{O}-\mathrm{Al}$ and $\mathrm{Si}-\mathrm{O}-\mathrm{Si}$ bonds of the zeolite with a weak peak at $793 \mathrm{~cm}^{-1}$ responsible for symmetrical coupling. The negative charge of zeolite surfaces allowed other cations to be added, especially the cations of ammonium and potassium, as well as the cationic surfactants HDTMA-Br. Surfactant-modified zeolites have the ability to adsorb anionic compounds such as phosphates or nitrates. The zeolite promoted the involvement of a cationic charge, such as ammonium and potassium cations, as well as amphiphilic compounds of the HDTMA-Br surfactant when phosphate ions were attached, to the formation of NPKOZ [49].

The leaching study found that NPKOZ showed less nutrient loss. For the study of plant growth, comparisons were made with eight different treatment methods, including chemical fertilizers ammonium phosphate and potassium phosphate for 70 days. The morphological parameters (number of flowers, branches and leaves, area of leaves and biomass of the plant) and biochemical growth parameters (N, P, K and chlorophyll content) of the plant were analyzed. A second cultivation was also conducted to compare potted, hydroponic and vertical systems with or without NPKOZ. NPKOZ treatment resulted in the highest number of leaves, branches and flowers among all the treatments. In addition, the chlorophyll content was also highest when using NPKOZ. The NPK content of $C$. asiatica plants was compared with that of the chemical fertilizers tested. This study showed that the NPKOZ complex fertilizer is a suitable fertilizer for the sustainable regulation of NPK release to improve the growth of $C$. asiatica [49].

In [50], an experiment was performed with modification of clinoptilolite by cationic surfactant, hexadecyltrimethylammonium bromide (HDTMA-Br), to obtain a surface-active modified clinoptilolite (SMC) which was subsequently added to a propagated substrate to form a controlled release substrate (CRPS). SMC was prepared by mixing $10 \mathrm{~g}$ of clinoptilolite with $200 \mathrm{ml}$ solution of HDTMA-Br at a concentration of $4 \mathrm{mmol} / \mathrm{L}$. The mixture was then stirred with a magnetic stirrer overnight. The mixture was filtered through $125 \mathrm{~mm}$ Advantec filter paper. The SMC solid residue was dried in an oven at $80^{\circ} \mathrm{C}$ overnight. Then the dried SMC was ground in a mortar to form a powder. For the preparation of controlled release propagating substrate (CRPS), various amounts of SMC (1 g, $7 \mathrm{~g}$, and $15 \mathrm{~g})$ were mixed uniformly with $50 \mathrm{~g}$ of propagation substrate and then homogenized to provide a uniform distribution of SMC in the propagating substrate. 
The release behavior of $\mathrm{PO}_{4}^{3-}, \mathrm{NO}_{3}^{-}$, and $\mathrm{K}^{+}$from CRPS was studied within ten days. The results showed that the combination of SMC with $50 \mathrm{~g}$ of propagation substrate can control the release of anions and cations and, in addition, enhance the growth of Clinacanthus nutans during sowing. Therefore, SMC should be added to the propagation substrate to control nutrient release during germination or sowing [50].

In [51], the authors investigate $\mathrm{NH}_{4}^{+}-\mathrm{K}^{+}$-loaded clinoptilolite (CLI) as a binary fertilizer. Three zeolite nutrient sources $(\mathrm{ZNSs})\left(\mathrm{NH}_{4}^{+}\right.$-saturated, $\mathrm{K}^{+}$-saturated and binary $\mathrm{NH}_{4}^{+}-\mathrm{K}^{+}$-saturated CLI) were manufactured, evaluated and compared with commercial fertilizers $\mathrm{N}$ and $\mathrm{K}(\mathrm{CFs})$ for corn growth in a greenhouse. The results showed that CLI could potentially adsorb both $\mathrm{NH}_{4}^{+}$and $\mathrm{K}^{+}$to maximum values of $25.00 \mathrm{mg}\left(\mathrm{NH}_{4}^{+}\right) / \mathrm{g}$ and $47.61 \mathrm{mg}\left(\mathrm{K}^{+}\right) / \mathrm{g}$, respectively, and chemisorption mainly accompanied the adsorption process. The saturation of the zeolite by $\mathrm{NH}_{4}^{+}$and $\mathrm{K}^{+}$ cations occurred after 10 and 15 days, resulting in ZNSs with $2 \%$ and $5 \% \mathrm{~N}$ and $\mathrm{K}$, respectively. $\mathrm{NH}_{4}^{+}-\mathrm{K}^{+}$saturated CLI contained $1 \% \mathrm{~N}$ and $1 \% \mathrm{~K}$. The maximum amount of sorbed $\mathrm{NH}_{4}^{+}$and $\mathrm{K}^{+}$by clinoptilolite during saturation was closely related to the maximum adsorption capacity predicted by the Langmuir model. Greenhouse experiment showed no significant difference between ZNSs and CFs on plant growth. However, the use of both $\mathrm{N}$ - and K-loaded zeolites significantly increased $\mathrm{N}$ uptake by the plant. The highest K uptake $(2.05 \mathrm{~g} / \mathrm{pot})$ occurred in plants supplied with both natural zeolite and CFs. The results of the greenhouse experiment confirm the integrity of the produced NK-CLI, N-CLI and KCL on corn growth with CFs-like effects. According to the results, CLI may be considered as a precursor for slow release fertilizer production in the fertilizer industry.

\section{Conclusions}

To date, improving the efficiency of fertilizers is an urgent task for agriculture to improve soil fertility, its physical and chemical properties. Uncontrolled use of fertilizers leads to environmental pollution. An analysis of current literature sources indicates that the use of zeolite-based composite materials as a prolonged fertilizer has a positive effect on plant nutrition, prevents leaching and promotes slow release of nutrients into the soil. Zeolite promotes the growth of plants, the development of their root system, retaining sufficient water in the root zone and preventing the leaching of nutrients. Application of zeolite fertilizers produce positive results in all types of soils and increase crop yields. Zeolites, due to their special crystalline structure, have excellent adsorption, ion exchange and catalytic properties. High cationic ability and strong affinity for $\mathrm{NH}_{4}^{+}$and $\mathrm{K}^{+}$allow them to be used for achieving maximum efficiency of nitrogen utilization in agriculture. Although almost all natural zeolites and most artificial zeolites do not have a high affinity for anionic fertilizers, the chemical modification of their surface by cationic surfactants can produce multifunctional adsorbents.

Soltys L. - PhD in Chemistry, Head of the educational laboratory of the Department of Chemistry;

Mironyuk I. - Professor, Doctor of Chemical Sciences, Head of the Department of Chemistry;

Tatarchuk T. - PhD in Chemistry, Associate Professor of the Department of Chemistry;

Tsinurchyn $\boldsymbol{V}$. - student of the $2^{\text {nd }}$ year of the Department of Chemistry.

[1] A. Lateef, R. Nazir, N. Jamil, S. Alam, R. Shah, M.N. Khan, M. Saleem, Microporous Mesoporous Mater., 232, 174 (2016) (https://doi.org/10.1016/j.micromeso.2016.06.020).

[2] S.A.A. Nakhli, M. Delkash, B.E. Bakhshayesh, H. Kazemian, Water, Air and Soil Pollution, 228, 464 (2017) (https://doi.org/10.1007/s11270-017-3649-1).

[3] Nalini Sharma, Ajay Singh, Int. J. Agric. Sci. Res., 9, 53 (2019) (https://doi.org/10.24247/ijasrapr20197).

[4] D. França, L.L. Messa, C.F. Souza, R. Faez, Polymers for Agri-Food Applications, 29 (2019) (https://doi.org/10.1007/978-3-030-19416-1_3).

[5] K. Lubkowski, Adv. Mater. Technol. Environ. Appl., 1(1), 38 (2017).

[6] J. Fu, C. Wang, X. Chen, Z. Huang, D. Chen, Commun. Soil Sci. Plant Anal., 49, 2219 (2018) (https://doi.org/10.1080/00103624.2018.1499757).

[7] M.Y. Naz, S.A. Sulaiman, Rev. Chem. Eng., 33, 293 (2017) (https://doi.org/10.1515/revce-2015-0065).

[8] M.H. Sazzad, T. Islam, A Review \& Outlook of Slow-Release Fertilizer: A breakthrough product for agronomy \& horticulture (Lambert Academic Publishing, Deutschland, Germany, 2013).

[9] M.E. Trenkel, Slow and Controlled-Release and Stabilized Fertilizers (International Fertilizer Industry Association, Paris, France, 2010) (https://doi.org/10.1017/CBO9781107415324.004).

[10] B. Azeem, K. Kushaari, Z.B. Man, A. Basit, T.H. Thanh, J. Control. Release, 181, 11 (2014) (https://doi.org/10.1016/j.jconrel.2014.02.020).

[11] [K. Ramesh, D.D. Reddy, Advances in Agronomy, 113, 219 (2011) (https://doi.org/10.1016/b978-0-12386473-4.00004-x).

[12] C. Sangeetha, P. Baskar, Agric. Rev., 37, 101 (2016) (https://doi.org/10.18805/ar.v0iof.9627).

[13] D. Bhardwaj, M. Sharma, P. Sharma, R. Tomar, J. Hazard. Mater., 227-228, 292 (2012) (https://doi.org/10.1016/j.jhazmat.2012.05.058).

[14] H.W. Pickering, N.W. Menzies, M.N. Hunter, Sci. Hortic. (Amsterdam), 94, 333 (2002) (https://doi.org/10.1016/S0304-4238(02)00006-7). 
[15] Z. Li, Y. Zhang, Y. Li, J. Plant Nutr., 36, 1496 (2013) (https://doi.org/10.1080/01904167.2013.790429).

[16] K. Ramesh, A.K. Biswas, A.K. Patra, Indian Journal of Agronomy, 60(2), 185 (2015).

[17] Web source: https://commons.wikimedia.org/wiki/File:Zeolite-ZSM-5-3D-vdW.png\#/media/Файл:ZeoliteZSM-5-3D-vdW.png.

[18] R. Ismawati, J. Pena Sains., 5, 57 (2018) (https://doi.org/10.21107/jps.v5i1.3199).

[19] Web-source: https://en.wikipedia.org/wiki/Zeolite.

[20] Ya.T. Suyundukov, H.M. Safin, M.B. Suyundukova, R.F. Hasanova, Ispol'zovanie prirodnyh ceolitov Zaural'ya Bashkortostana dlya povysheniya plodorodiya pochv i urozhajnosti sel'skohozyajstvennyh kul'tur (Izdatel'skij dom "Respublika Bashkortostan", 2017).

[21] S.G. Yagolnyk, Ochyshennya stichnykh vod vid pryamyh barvnykiv aktyvovanym klinoptilolitom Avtoreferat dysertaciyi na zdobuttya naukovogo stupenya kand.tehn.nauk (NU "Lvivska politehnika", Lviv, 2008).

[22] T. Kurniawan, Nuryoto, M.A. Firdaus, World Chemical Engineering Journal, 3(1), 14 (2019).

[23] L. Seifi, A. Torabian, H. Kazemian, G.N. Bidhendi, A.A. Azimi, S. Nazmara, M. Alimohammadi, Clean Soil, Air, Water., 39(10), 939 (2011) (https://doi.org/10.1002/clen.201000390).

[24] R.S. Bowman, Microporous Mesoporous Mater., 61, 43 (2003) (https://doi.org/10.1016/S13871811(03)00354-8).

[25] H. Kazemian, K. Gedik, I. Imamoglu, Handbook of natural zeolites, 473 (2012) (https://doi.org/10.2174/97816080526151120101).

[26] N. Mehrab, M. Chorom, S. Hojati, Commun. Soil Sci. Plant Anal., 47, 1306 (2016) (https://doi.org/10.1080/00103624.2016.1166377).

[27] G.M. Gospodarenko, Systema zastosuvannya dobryv: Navch. posibnyk (SIK GRUP, Kyiv, 2015).

[28] G.M. Gospodarenko, Agrohimiya (SIK GRUP, Kyiv, 2018).

[29] S. Sfechis, R. Vidican, M. Sandor, V. Stoian, V. Sandor, B. Muste, ProEnvironment/ProMediu, 8, 85 (2015).

[30] R. Sarkar, B. Naidu, Nutr. Use Effic. from Basics to Adv., 29 (2015): (https://doi.org/10.1007 / 978-81-3222169-2_3).

[31] S. Torma, J. Vilcek, P. Adamisin, E. Huttmanova, O. Hronec, Turkish J. Agric. For., 38, 739 (2014) (https://doi.org/10.3906/tar-1311-13).

[32] M. Gholamhoseini, A. Ghalavand, A. Khodaei-Joghan, A. Dolatabadian, H. Zakikhani, E. Farmanbar, Soil Tillage Res., 126, 193 (2013) (https://doi.org/10.1016/j.still.2012.08.002).

[33] J. Vilcek, S. Torma, P. Adamisin, O. Hronec, Bulg. J. Agric. Sci., 19, 228 (2013).

[34] A.R. Piñón-Villarreal, A.S. Bawazir, M.K. Shukla, A.T. Hanson, J. Irrig. Drain. Eng., 139, 755 (2013) (https://doi.org/10.1061/(ASCE)IR.1943-4774.0000618).

[35] S.S. Lim, D.S. Lee, J.H. Kwak, H.J. Park, H.Y. Kim, W.J. Choi, J. Soils Sediments, 16, 756 (2016) (https://doi.org/10.1007/s11368-015-1294-0).

[36] N. Colombani, M. Mastrocicco, D.Di Giuseppe, B. Faccini, M. Coltorti, Catena., 127, 64 (2015) (https://doi.org/10.1016/j.catena.2014.12.022).

[37] H. Taheri-Sodejani, M. Ghobadinia, S.H. Tabatabaei, H. Kazemian, Desalination and Water Treatment, 54, 2723 (2015) (https://doi.org/10.1080/19443994.2014.904818).

[38] J.A. Ippolito, D.D. Tarkalson, G.A. Lehrsch, $\quad$ Soil $\quad$ Sci., $\quad 176, \quad 136 \quad$ (2011) (https://doi.org/10.1097/SS.0b013e31820e4063).

[39] R. Malekian, J. Abedi-Koupai, S.S. Eslamian, J. Hazard. Mater., 185, 970 (2011) (https://doi.org/10.1016/j.jhazmat.2010.09.114).

[40] A. Molla, Z. Ioannou, A. Dimirkou, K. Skordas, Chem. Mater. Sci., 7, 38 (2014).

[41] M. Gholamhoseini, M. AghaAlikhani, A. Dolatabadian, A. Khodaei-Joghan, H. Zakikhani, Agron. J., 104, 1467 (2012) (https://doi.org/10.2134/agronj2012.0145).

[42] I. Lancellotti, T. Toschi, E. Passaglia, L. Barbieri, Environ. Sci. Pollut. Res., 21, 13237 (2014) (https://doi.org/10.1007/s11356-014-3334-5).

[43] R. Fujinuma, M. Hunter, N. Menzies, Acta Hortic., 1104, 21 (2015) (https://doi.org/10.17660/ActaHortic.2015.1104.4).

[44] A.K. Bansiwal, S.S. Rayalu, N.K. Labhasetwar, A.A. Juwarkar, S. Devotta, J. Agric. Food Chem., 54, 4773 (2006) (https://doi.org/10.1021/jf060034b).

[45] N.S. Dionisiou, T. Matsi, N.D. Misopolinos, Water, Air and Soil Pollution, 224, 1362 (2013) (https://doi.org/10.1007/s11270-012-1362-7).

[46] J. Zheng, T. Chen, D. Chi, G. Xia, Q. Wu, G. Liu, W. Chen, W. Meng, Y. Chen, K.H.M. Siddique, Agronomy, 9, 537 (2019) (https://doi.org/10.3390/agronomy9090537).

[47] D. Moraetis, S. Papagiannidou, A. Pratikakis, D. Pentari, K. Komnitsas, Desalination and Water Treatment, 57 (28), 13273 (2016) (https://doi.org/10.1080/19443994.2015.1065440). 
[48] K.A. Rabai, O.H. Ahmed, S. Kasim, Emirates Journal of Food and Agriculture, 25 (9), 713 (2013) (https://doi.org/10.9755/ejfa.v25i9.16248).

[49] N.A.N. Azman, N.A.N.N. Malek, N.S.M. Noor, M.A. Javed, Futur. Food J. Food, Agric. Soc., 6, 55 (2018).

[50] N.H. Dzkulfli, N.S. Hamzah, W.M. Madhi, W. Abdullah, N.I.K. Ahmad, N. Nik, Proceeding of 2nd International Science Postgraduate Conference (Faculty of Science, Universiti Teknologi Malaysia, 2014), p. $1-11$.

[51] M. Eslami, R. Khorassani, A. Fotovat, A. Halajnia, Archives of Agronomy and Soil Science, 1 (2019) (https://doi.org/10.1080/03650340.2019.1591617).

\title{
Л.М. Солтис, І.Ф. Миронюк, Т.Р. Татарчук, В.І. Цінурчин
}

\section{Композиційні добрива пролонгованої дії на основі цеоліту (огляд)}

\author{
ДВНЗ «Прикарпатський наиіональний університет імені Василя Стефаника», Івано-Франківськ, Украӥна, \\ e-mail:soltys86@gmail.com
}

\begin{abstract}
Однією 3 сучасних важливих проблем сільського господарства $€$ пошук нових методів для підвищення родючості та продуктивності грунту. Внесення добрив збільшує ефективність поживних речовин, однак, неконтрольоване їх використання призводить до вилуговування грунтів та забруднення навколишнього середовища. Цеоліт вважається природним елементом, що немає негативних екологічних впливів. Його іонообмінні властивості $\epsilon$ важливими для живлення рослин завдяки катіоно-обмінній здатності та пористості. Цеоліти, додані до добрив, дають подвійний результат при внесенні у грунт: забезпечують тривалу дію добрива (ефект пролонгації) та запобігають вимиванню поживних речовин. У даній статті приведений аналіз сучасних літературних джерел інформації щодо застосування композитних матеріалів на основі цеоліту як добрив пролонгованої дії у сільському господарстві, а також їх впливу на утримування та вивільнення поживних речовин у грунт.

Ключові слова: цеоліт, добрива повільного вивільнення, ПАР-модифікований цеоліт, вилуговування, поглинання поживних речовин, утримування, катіоно-обмінна здатність, поліпшувачі грунту.
\end{abstract}

